
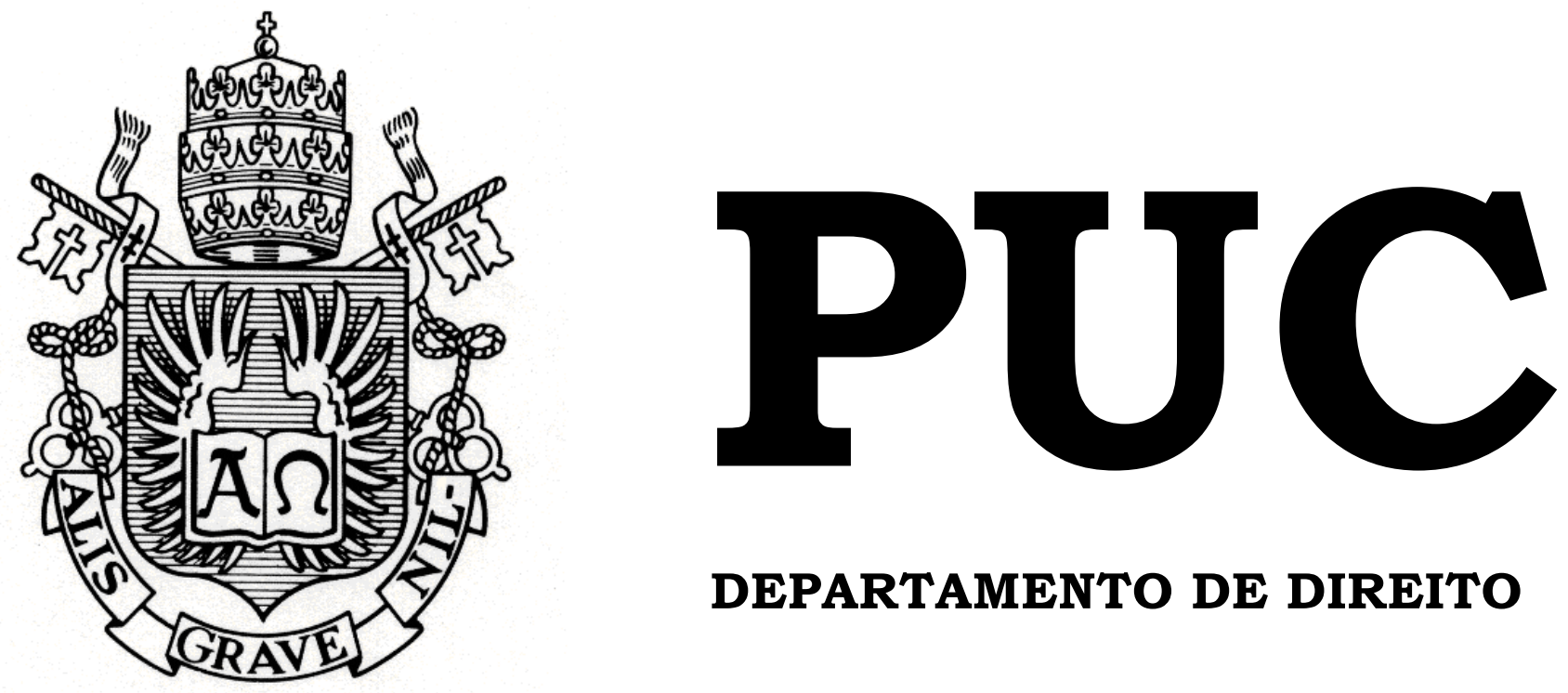

DEPARTAMENTO DE DIREITO

\title{
TERCEIRO SETOR: ORGANIZAÇÕES SOCIAIS
}

\author{
por
}

LAILA FEDERICO ASFORA

ORIENTADOR: PROF. MANOEL MESSIAS PEIXINHO

2012.1

PONTIFÍCIA UNIVERSIDADE CATÓLICA DO RIO DE JANEIRO

RUA MARQUÊS DE SÃO VICENTE, 225 - CEP 22453-900

RIO DE JANEIRO - BRASIL 


\title{
TERCEIRO SETOR: ORGANIZAÇÕES SOCIAIS
}

\author{
por
}

\section{LAILA FEDERICO ASFORA}

Monografia apresentada ao Departamento de Direito da Pontificia Universidade

Católica do Rio de Janeiro (PUC-Rio) como requisito parcial para obtenção do Titulo de Bacharel em Direito.

Orientador: Professor Doutor Manoel Messias Peixinho 


\section{AGRADECIMENTOS}

A Deus, pois sem ele eu não teria forças para essa longa jornada;

Aos meus pais, Murilo de Souza Asfora e Conchita Federico Asfora pelo apoio, compreensão, amor incondicional e por nunca terem medido esforços na realização dos meus sonhos;

À minha tia Anna Federico e à minha prima Michelle Roza Federico pela ajuda e por todo carinho ao longo desse percurso;

À Luzimar de Lima pelos cafés e lanches durante toda essa longa jornada

Ao meu namorado Raphael Beltrão pelo incentivo e confiança, todo meu amor;

A todos meus amigos, queridos e especiais, que contribuíram de alguma forma para a elaboração do presente trabalho, minha eterna gratidão;

A todos os professores do curso que foram tão importantes na minha vida acadêmica, em especial à professora Marianna Montebello Willeman; e

Ao meu querido orientador Manoel Messias Peixinho, pela paciência na orientação, carinho e incentivo que tornaram possível a conclusão desta monografia. 


\section{RESUMO}

O presente trabalho trata das organizações sociais, integrantes do Terceiro Setor, no âmbito federal, previstas na lei federal $n^{\circ}$ 9.637/98, como uma nova parceria entre Estado e entidades privadas para a prestação de serviços não exclusivos relacionados à educação, à pesquisa científica, desenvolvimento tecnológico, à proteção e à preservação do meio ambiente, à cultura e à saúde.

No primeiro capítulo, será abordado o surgimento do terceiro setor, com o objetivo é facilitar a compreensão das razões que desencadearam sua criação. Além disso, também serão apresentados alguns aspectos gerais sobre este setor, bem como o contexto da criação da lei das organizações sociais e as noções gerais acerca do referido diploma legal.

No segundo capítulo, será analisado o procedimento de licitação no ordenamento jurídico brasileiro, a definição deste procedimento, seus princípios norteadores e a obrigatoriedade de sua observância por parte do Poder Público.

O terceiro capítulo, por sua vez, versa sobre a problemática do procedimento licitatório nas organizações sociais. Tratam-se, com efeito, de quatro perspectivas sobre o tema, quais sejam: (i) o processo de escolha da organização social que firmará com o Estado contrato de gestão; (ii) a contratação da organização social para prestação de atividades previstas no contrato de gestão; (iii) as contratações de serviços, bens e obras por parte das OS ; e (iv) a remessa de bens públicos às OS.

Por fim, o quarto e último capítulo tratará das questões suscitadas na Ação Direta de Inconstitucionalidade $\mathrm{n}^{\mathrm{o}} 1.923-\mathrm{DF}$, no que tange a constitucionalidade da denominada Lei das Organizações Sociais (Lei $n^{0}$ 9.637/98), especialmente sobre o procedimento de licitação.

\section{PALAVRAS-CHAVE}

Terceiro Setor. Evolução. Organizações Sociais. Lei 9637/98. Aspectos Gerais. Procedimento Licitatório. Definição. Princípios. Dispensa de Licitação. Contrato de Gestão. Contratação. Divergência Doutrinária. STF. ADIN 1923-DF. 


\section{SUMÁRIO}

CAPÍTULO 1 - INTRODUÇÃO .....................................................6

CAPÍTULO 2 - TERCEIRO SETOR E AS ORGANIZAÇÕES

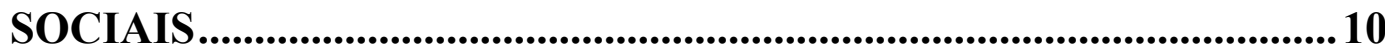

2.1 - Da contextualização do Terceiro Setor ………………………..... 10

2.2 - Aspectos gerais sobre o Terceiro Setor ……………………........ 12

2.3 - O marco legal de surgimento das organizações sociais ................ 16

2.4 - Observações acerca da Lei 9.637/98 ............................................ 18

CAPÍTULO 3 - O PODER PÚBLICO E O DEVER DE LICITAR ...25

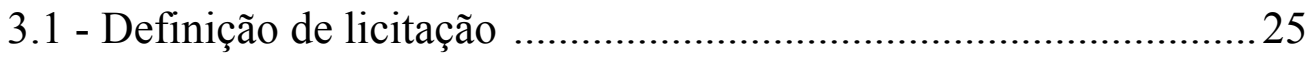

3.2 - Princípios norteadores da licitação .............................................28

3.3 - Considerações gerais sobre a Lei 8.666/93 …………………...... 32

CAPÍTULO 4 - A PROBLEMÁTICA DA LICITAÇÃO NAS

ORGANIZAÇÕES SOCIAIS ..........................................................................38

4.1 - A escolha das Organizações Sociais para celebração de contrato de gestão com a Administração Pública …………………………........39

4.2 - Contratações das OS derivadas do contrato de gestão ...................45

4.3 - Obrigatoriedade de regulamento próprio das OS na contratação de empresas prestadoras de serviços, de realização de obras e de

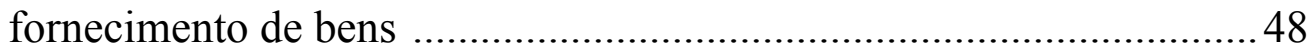

4.4 - Destinação de recursos orçamentários e bens públicos para as

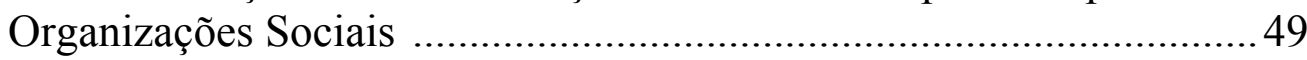

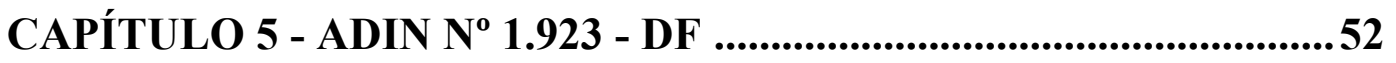

5.1 - Petição inicial da Ação Direta de Inconstitucionalidade

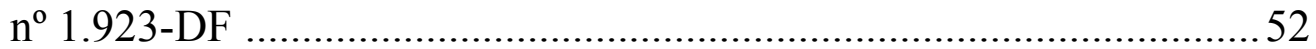

5.2 - Síntese dos votos dos Exmos. Ministros Ayres Britto e

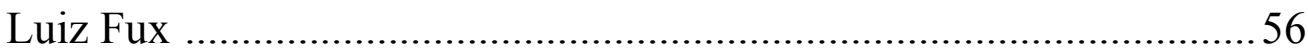

5.3 - Análise crítica dos votos da ADIN no que concerne à obrigatoriedade da licitação .................................................................. 66

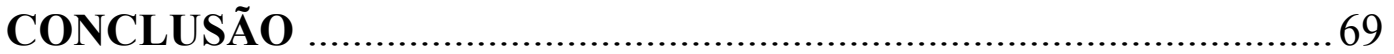

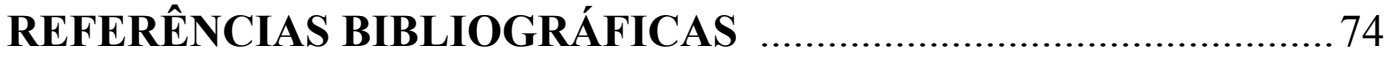




\section{ABREVIAÇÕES E SÍMBOLOS}

ADIN - Ação direta de inconstitucionalidade

Art. - Artigo

CF - Constituição Federal

$n^{0}$ - número

OS - Organizações Sociais

OSCIP- Organizações de Sociedade Civil de Interesse Público

p. - página

vol. - volume 


\section{CAPÍTULO 1 - INTRODUÇÃO}

Com o advento do Estado Democrático de Direito, consolidado na soberania popular, a sociedade exige cada vez mais participação em atividades que antes eram exclusivas do Estado. Esse contexto marca uma aproximação entre Estado e sociedade, com o estreitamento de sua relações, o que pode ser verificado através do surgimento de entes intermediários, determinando uma crescente interseção entre a atuação estatal e particular.

Há, hodiernamente, uma ruptura da tradicional dicotomia entre direito público e privado e o paradigma da consensualidade ganha relevância no direito administrativo brasileiro. Nesse sentido, sustenta-se a necessidade de transformação do aparelho estatal, visando a atender da melhor forma possível as demandas sociais, especialmente no que concerne à prestação de serviços públicos e à efíciência do gerenciamento da coisa pública.

Atualmente, a participação dos particulares em atividades de interesse público tem aumentado paulatinamente por meio da instituição de várias formas de parceria. No que diz respeito, por exemplo, à ordem econômica $\mathrm{e}$ social, o Poder Público passou a se concentrar mais nas funções de regular, estimular e promover as atividades realizadas pelos particulares do que na função de prestação direta dos serviços.

A Constituição de 1988 teve papel relevante neste fenômeno, na medida em que permitiu que os serviços sociais sejam prestados tanto pelos particulares quanto pelo próprio Estado. É importante notar que quando a prestação for exercida pelos particulares, as atividades deverão obedecer as normas do direito privado, com certas derrogações de direito público, ao passo que, quando forem prestadas pelo Estado, deverão ser regidas pelo regime jurídico de direito público. A Constituição Federal dispõe ainda que quando os particulares prestarem os serviços por direito próprio, e sem o 
intuito de lucro, o Estado deverá auxiliá-los por intermédio de atividades de fomento.

Na década de 90, surgiu no Brasil a chamada Reforma do Aparelho do Estado que procurava reestruturar a Administração Pública, bem como garantir uma administração mais eficiente e voltada para a cidadania. Tal processo teve seu maior impulso a partir da aprovação do Plano Diretor da Reforma do Aparelho do Estado (PDRAE), elaborado pelo Ministério da Administração e Reforma do Estado (MARE), criado com o fim de efetivar a reforma administrativa pretendida pelo Governo Federal.

Neste momento, foi criada uma nova estrutura administrativa composta pelo Primeiro Setor, formado pelos três poderes; Segundo Setor, formado para prestação de serviços exclusivos do Estado; e Terceiro Setor, composto pelas OS, OSCIP, entidades de apoio e serviços sociais autônomos, cuja disciplina será a área de incidência do presente trabalho monográfico.

O Terceiro Setor possui, ainda, como fundamento o princípio da subsidiariedade, que implica dizer que o Estado só deve atuar quando o particular não tiver mais condições de fazê-lo sozinho, hipótese em que deve estimular e ajudar a iniciativa privada.

Ademais, o fomento também é um dos pilares da parceria entre o Terceiro Setor e o Poder Público. Isto porque, o papel desse setor é criar mecanismos para que os cidadãos e a sociedade civil satisfaçam os interesses da coletividade, permitindo, dessa forma, que as entidades privadas não lucrativas desempenhem atividades de condão social, fora dos limites do Estado, porém incentivadas por ele; são os denominados serviços não exclusivos do Estado. 
No tocante as atividades de interesse social, essa transformação amplia a atividade de fomento ao setor privado não estatal, com o objetivo de atingir de forma mais eficiente os interesses públicos.

Portanto, o presente trabalho trata de alguns aspectos da evolução do direito administrativo, que desencadeiam na valorização do terceiro setor, sendo este, por sua vez, a categoria na qual se inserem as organizações sociais, objeto deste estudo.

Um dos itens do mencionado Plano de Reforma do Estado foi a aprovação do "Programa Nacional de Publicização", através da Lei $n^{\mathbf{0}}$ 9.637, de 15 de Maio de 1998, que permite que o Poder Executivo transfira a execução de serviços públicos e de gestão de bens e pessoal públicos à entidades qualificadas como Organizações Sociais.

Trata-se de uma forma de parceria entre entidades de direito privado sem fins lucrativos e o Poder Público, para desempenhar serviços sociais não exclusivos do Estado, devidamente incentivados e fiscalizados, mediante vínculo jurídico instituído por meio de contrato de gestão.

Por conta das vantagens atípicas e excessivas outorgadas às organizações sociais por intermédio do contrato de gestão, tem-se discutido a constitucionalidade de diversas disposições da Lei $\mathrm{n}^{\circ} 9.637 / 98$, tendo em vista que tais benefícios auferidos por essas entidades privadas contrariam frontalmente princípios da Administração Pública, sobretudo em que pese o procedimento licitatório das OS.

De acordo com o disposto no art. 37, XXI da Constituição Federal de 1988, é obrigatória a observância de licitação para todas as aquisições de bens e contratações de serviços e obras, assim como para alienação de bens, realizados pela Administração no exercício de suas funções, o que consiste no denominado dever de licitar por parte do Poder Público. 
Em atendimento a esta regra constitucional, a Lei $\mathrm{n}^{\mathrm{o}}$ 8.666/93 estabelece normas gerais sobre licitações e contratos administrativos pertinentes a serviços e obras no âmbito da Administração Pública, prevendo os princípios, a forma, o objeto e as demais regras que deverão ser observadas nos procedimentos licitatórios realizados pelo Estado.

Em contrapartida, o principal aspecto a ser observado na presente monografia é que o artigo 24, inciso XXIV da Lei $n^{\circ} 8.666 / 93$ prevê uma hipótese de dispensa de licitação, admitindo a contratação direta de organizações sociais pela Administração Pública. A partir dessa disposição, há uma problemática em torno do procedimento licitatório nas OS, conforme será paulatinamente desenvolvido nos capítulos seguintes.

Para melhor visualização da referida problemática, serão analisados os posicionamentos doutrinários acerca do tema, com a finalidade de demonstrar a necessidade do procedimento licitatório em determinadas hipóteses.

Com efeito, a lei das OS foi objeto de muitas críticas tanto na doutrina quanto na jurisprudência, dando ensejo à propositura da ADIN no $1923-\mathrm{DF}$ perante o Supremo Tribunal Federal, que busca o reconhecimento da inaplicabilidade de diversos de seus dispositivos, principalmente no que tange à questão da obrigatoriedade de licitação.

No presente estudo, serão pontuados os principais fundamentos jurídicos em discussão na $\mathrm{ADIN} \mathrm{n}^{\circ} 1.923-\mathrm{DF}$, a partir de uma análise crítica dos votos proferidos pelos Exmos. Ministros Ayres Britto e Luiz Fux, a fim de se estabelecer novos apontamentos sobre o tema, bem como corroborar as alegações aduzidas por outros ilustres juristas de Direito Administrativo. 


\section{CAPÍTULO 2 - TERCEIRO SETOR E AS ORGANIZAÇÕES SOCIAIS}

\section{1 - Da contextualização do Terceiro Setor}

O direito administrativo brasileiro sofreu inúmeras inovações após a promulgação da Constituição Federal de 1988, que institui o Estado Democrático de Direito, em exaltação a ideia de valorização da sociedade civil. Nesse contexto, observa-se uma administração pública cidadã, na qual se exige maior participação social nas atividades realizadas pelo Estado na medida em que a soberania popular é cada vez mais exaltada.

Houve, a partir deste período, uma tendência de socialização, sobretudo no que se refere à preocupação com os bens e com o interesse público. Conforme constata Maria Sylvia Zanella Di Pietro, “com a nova concepção do Estado de Direito, o interesse público humaniza-se à medida que passa a preocupar-se não só com os bens materiais que a liberdade de inciativa almeja, mas também com valores considerados essenciais à existência digna (...) e passa a confundir-se com a ideia de bem comum."

Por outro lado, essa mutação que ocorreu no Estado foi resultado, sobretudo, do princípio da eficiência, ${ }^{2}$ que representa a qualidade essencial que a administração deve perseguir, tanto em sua atuação externa quanto interna. Tal princípio informa que o Poder Público deve produzir um conjunto de resultados em benefício da sociedade, buscando a produção de bens e serviços de melhor qualidade e com menores custos para efetivamente atender as demandas sociais.

\footnotetext{
${ }^{1}$ DI PIETRO, Maria Sylvia Zanella. Parcerias na Administração Pública. São Paulo: Atlas, 2011, p. 14.

${ }^{2}$ MOREIRA NETO, Diogo de Figueiredo. Quatro Paradigmas do Direito Administrativo PósModerno: legitimidade: finalidade: eficiência: resultados. Belo Horizonte: Fórum, 2008, p. 103.
} 
Como se observa, o alcance dessa nova concepção de eficiência significa que não importa quem é o prestador do serviço, pois o principal objetivo é a satisfação das demandas sociais da melhor forma e com redução de recursos financeiros.

Outro basilar para a mudança verificada foi a consagração do princípio da subsidiariedade, ${ }^{3}$ que determina que o Estado somente deve estimular, subsidiar a atividade quando a iniciativa privada não tiver condições de atuar sozinha. Logo, o interesse público passa a refletir os interesses dos cidadãos e não mais os interesses da máquina administrativa.

Ademais, é inerente a esse princípio a noção de que o Estado deve fiscalizar, fomentar e coordenar a iniciativa privada, até mesmo por meio de parcerias entre o público e o privado, com a finalidade de subsidiar a iniciativa privada deficiente.

A partir desse novo "modelo" estatal, as atividades da Administração Pública devem ser desempenhadas de forma mais eficiente e efetiva, adequando-se às demandas e às mazelas sociais.

Neste contexto, foi criado, no Brasil, o Plano Diretor da Reforma do Aparelho do Estado, ${ }^{4}$ que possui como objetivo a prestação dos serviços por parte da Administração de forma mais eficaz aos cidadãos. Com o intuito de atender ao interesse público, pode-se observar a criação de mecanismos de colaboração entre o Estado e os particulares.

Esse cenário dá origem ao terceiro setor. Nesse sentido, para Ruth Cardoso, "o Terceiro Setor descreve um espaço de participação $e$

\footnotetext{
${ }^{3}$ OLIVEIRA, Rafael Carvalho Rezende. Administração Pública, Concessões e Terceiro Setor. Rio de Janeiro: Lumen Juris, 2009, p. 277.

${ }^{4}$ BRASIL, Presidente. PLANO DIRETOR DA REFORMA DO APARELHO DO ESTADO:

Presidência da República, Câmara da Reforma do Estado, Ministério da Administração Federal e Reforma do Estado, 1995, p. 54.

${ }^{5}$ CARDOSO, Ruth. Fortalecimento da sociedade civil. In: IOSCHPE, E. B. (org.). Terceiro

Setor: Desenvolvimento Social Sustentado. 2a. ed. São Paulo: GIFE, 2000, p. 8.
} 
experimentação de novos modelos de pensar e agir sobre a realidade social".

\section{2 - Aspectos gerais sobre o Terceiro Setor}

O Terceiro Setor é composto por entidades privadas que prestam atividade de interesse social, sem fins lucrativos. A expressão Terceiro Setor surgiu no Brasil na década de 1970, traduzida do inglês Third Sector, para se diferenciar do primeiro e do segundo setor. Embora o ordenamento jurídico brasileiro ainda não contenha uma definição precisa para tal expressão. Gustavo Henrique Justino de Oliveira esclarece o terceiro setor como:

O conjunto de atividades voluntárias, desenvolvidas por organizações privadas nãogovernamentais e sem animo de lucro, realizadas em prol da sociedade, independentemente dos demais setores, embora com eles possa firmar parcerias e deles possa receber investimentos. ${ }^{6}$

Neste mesmo sentido, Marçal Justen Filho define terceiro setor como o conjunto "integrado por sujeitos e organizações privadas que se comprometem com a realização de interesses coletivos e a proteção de valores supra individuais". ${ }^{7}$

Em outras palavras, conceitua-se terceiro setor como o conjunto de pessoas jurídicas de direito privado, de caráter voluntário e sem fins lucrativos, que desenvolvam atividades de defesa e promoção dos direitos fundamentais ou prestem serviços públicos de interesse público. ${ }^{8}$

\footnotetext{
${ }^{6}$ OLIVEIRA, Gustavo Henrique Justino de. Estado contratual, direito ao desenvolvimento e parceria público- privada. In: TALAMINI, Eduardo et al. ( Coord.). Parceria público-privada: uma abordagem multidisciplinar. São Paulo: Revista dos Tribunais, 2005. p. 86.

${ }^{7}$ JUSTEN FILHO, Marçal. Curso de direito administrativo. São Paulo: Saraiva, 2005. p. 130.

${ }^{8}$ MÂNICA, Fernando Borges. Panorama Histórico- legislativo do terceiro Setor no Brasil: Do conceito de Terceiro Setor à Lei das OSCIP. In: OLIVEIRA, Gustavo Henrique Justino de. Direito do Terceiro Setor: Atualidades e Perspectivas. Curitiba: Ordem dos advogados do Brasil, Seção do Paraná, 2006. p. 26.
} 
Vale acrescentar que o primeiro setor se refere ao Estado propriamente dito, composto pela Administração Pública direta e indireta, enquanto o segundo setor corresponde à iniciativa privada voltada às atividades econômicas, com fins lucrativos.

A obra de Rafael Carvalho Rezende Oliveira faz a distinção entre os três setores da Administração Publica brasileira:

A expressão 'Terceiro Setor', que engloba as entidades da sociedade civil sem fins lucrativos, surge justamente como uma 'terceira via' possível no atendimento do interesse público. Usualmente, o Primeiro Setor, formado pelo Estado, e o Segundo Setor, relativo ao mercado (entidades privadas com fins lucrativos, tais como os concessionários e os permissionários de serviços públicos), eram os responsáveis pelo atendimento do interesse público. Atualmente, como visto, em virtude da aproximação entre o estado e a sociedade civil, a iniciativa privada, que presta atividades socialmente relevantes, vai ser fomentada, notadamente, pelo recebimento de benefícios públicos. Em verdade, as entidades que integram o Terceiro Setor não representam novidades intrínsecas do ponto de vista organizacional. (...) O que existe de novidade, destarte, é a qualificação jurídica que será atribuída a tais entidades. ${ }^{9}$

O terceiro setor possui como objetivo incentivar a prestação de serviços de interesse da coletividade por pessoas privadas, pressupondo, de outro lado, o atendimento a uma finalidade pública. Frise-se que as entidades que compõem $\mathrm{o}$ terceiro setor não são integrantes da Administração Publica direta ou indireta, embora desempenhem serviços em colaboração com o Estado, buscando atender ao interesse social.

Atualmente, tal setor deve ser analisado como um meio termo entre o público e o privado, possuindo um regime jurídico híbrido, pautado predominantemente por normas do direito privado, mas também sofrendo a incidência do direito público. Por exemplo, se alguma entidade do terceiro setor recebe auxílio financeiro do Estado, esta será submetida ao controle exercido pelo Tribunal de Contas.

O resultado do terceiro setor é uma cidadania ativa, na qual os particulares colaboram no desempenho das atividades, proporcionando um

\footnotetext{
${ }^{9}$ OLIVEIRA, Rafael Carvalho Rezende. Administração Pública, Concessões e Terceiro Setor. Rio de Janeiro: Lumen Juris, 2009, p. 277.
} 
desenvolvimento da ação pública. Cumpre observar, neste ponto, que existe uma maior cooperação entre o Estado e a sociedade com o fim de melhor aproveitar os recursos públicos destinados às atividades públicas não exclusivas do Estado, mais especificamente, serviços públicos sociais, tais como saúde, educação, cultura e etc..

Maria Sylvia Zanella Di Pietro aponta algumas características comuns acerca das entidades que compõem o terceiro setor. Esta autora entende que tratam-se de organizações não governamentais- que não são criadas pelo Estado- mas que possuem vínculos jurídicos com o poder publico, seja por meio de contrato de gestão, termo de parceria, convênios, lei, ou mediante o repasse de recursos públicos que recebem para realizarem serviços em colaboração com o Poder Público.

Ademais, a referida autora afirma que:

Em regra, não desempenham serviço público delegado pelo estado, mas atividade privada de interesse público; trata-se dos chamados serviços sociais não exclusivos do Estado; quando prestados por este, sob regime jurídico de direito público, são serviços públicos; quando prestados pelo particular, são atividades privadas de interesse público, que alguns chamam de serviços públicos impróprios. Elas desempenham serviços não exclusivos do Estado, mas atuam em colaboração com ele. $^{10}$

Portanto, no atual contexto, estas instituições protetivas são os novos atores que determinam o efetivo crescimento social e econômico do Brasil. E, por essa razão, críticas surgem em relação aos diplomas legais que regulam o terceiro setor.

Embora existam diversos enquadramentos pela doutrina, considerarse-ão integrantes deste setor os serviços sociais autônomos, os entes de apoio, as organizações sociais e as organizações da sociedade civil de interesse público.

\footnotetext{
${ }^{10}$ DI PIETRO, Maria Sylvia Zanella. Direito Administrativo. 25a. ed. São Paulo: Atlas, 2012. p 551 .
} 
A Lei $n^{0}$ 9.790/99 versa sobre a Organização da Sociedade Civil de Interesse Público, que prestam serviço público não exclusivo do Estado através do vinculo jurídico constituído por meio de termo de parceria.

A aludida Lei possui como objetivo a adoção de mecanismos de apoio do Estado ao terceiro setor, mais simplificados para afastar a excessiva formalidade e burocracia estatais. Insta ressaltar que se preenchidos os requisitos para criação do termo de parceria, conforme a Lei 9.790/99, o Estado tem o dever de fazê-lo.

Sua habilitação é feita pelo Ministério da Justiça. Por receberem recursos públicos, há a exigência da realização de licitação para obras, alienações, serviços e compras.

Por sua vez, os serviços sociais autônomos, também chamados de "Sistema S", dependem de lei para exercício de atividade de fomento, para capacitação de certas categorias profissionais. $\mathrm{O}$ fato de serem custeados por contribuições compulsórias pagas pelos sindicalizados, enseja controle por parte da Administração Pública e do Tribunal de Contas, sendo necessário, ademais, observar a licitação instituída na Lei no 8.666/93.

As entidades de apoio são entidades privadas que atuam ao lado de hospitais públicos ou universidades públicas auxiliando nas atividades de pesquisa, ensino, extensão e desenvolvimento científico, mediante convênio. A seu turno, também recebem recursos públicos, tendo que cumprir a exigência de seguir o procedimento licitatório comum.

Por fim, o processo de Reforma do Estado criou as entidades denominadas de Organizações Sociais, objeto de estudo do próximo item. 


\section{3 - O marco legal de surgimento das organizações sociais}

$\mathrm{Na}$ década de 80 , a busca da eficiência, a expansão dos meios de comunicação de massa e a redemocratização do país motivaram a sociedade brasileira a reclamar maior participação nas atividades de interesse público.

Nesse contexto, a Constituição Federal promulgada em 1988 prestigiou mecanismos de participação da sociedade civil, estimulando o dever de colaboração entre o Estado e a iniciativa privada. Como referido, essa mudança na forma de atuação do Poder Público foi exteriorizada através do Plano Diretor da Reforma do Estado, voltado para o atendimento dos cidadãos.

Para tanto, foram criados quatro setores de atuação do Estado, quais sejam: ${ }^{11}$

a) Núcleo Estratégico. Corresponde ao governo em sentido lato. É o setor que define as leis e as políticas públicas, e cobra seu cumprimento. (...);

b) Atividades Exclusivas. É o setor que são prestados serviços que só o Estado pode realizar. São serviços em que se exerce o poder extroverso do Estado - o poder de regulamentar, fiscalizar, fomentar. Como exemplos temos: a cobrança e fiscalização dos impostos, a polícia, a previdência social básica, o serviço de desemprego, a fiscalização do cumprimento de normas sanitárias, o serviço de trânsito, a compra de serviços de saúde pelo Estado, o controle do meio ambiente, o subsídio à educação básica, o serviço de emissão de passaportes etc.;

c) Serviços não exclusivos. Corresponde ao setor onde o Estado atua simultaneamente com outras organizações privadas ou públicas não-estatais e privadas (...). São exemplos desse setor: as universidades, os hospitais, os centro de pesquisa e os museus;

d) Produção de bens e serviços para o mercado. Corresponde à área de atuação das empresas. É caracterizado pelas atividades econômicas voltadas para o lucro (...).

O setor dos serviços não-exclusivos do Estado, que ora nos interessa, é composto por atividades desenvolvidas conjuntamente entre a iniciativa privada, o Estado e o Terceiro Setor.

\footnotetext{
${ }^{11}$ SILVA, Carlos Medeiros. Revista de Direito Administrativo. 230a. ed. Rio de Janeiro: Renovar Ltda., 2002. p 79.
} 
A Constituição Federal de 1988 prevê em seu artigo 37, caput que a atuação da Administração Pública deve estar sempre pautada no princípio da eficiência. Dessa forma, a transferência dos serviços estatais para o setor privado só é cabível quando tornar mais eficiente e qualificada a prestação das atividades de interesse coletivo.

O Plano de Reforma previu a criação das organizações sociais por meio da instituição do Programa Nacional de Publicização, para suprir a necessidade de se ampliar a descentralização dos serviços públicos.

Vale ressaltar que autores como José Carvalho Filho ${ }^{12}$ e Marcelo Alexandrino ${ }^{13}$ explicam que o termo "publicização" fora utilizado de modo inadequado, tendo em vista que a atividade não é deslocada do privado para o público e sim, o contrário. Sendo assim, a expressão mais conveniente seria desestatização.

O mencionado programa tem como intenção transformar hospitais e universidades públicas, centros de pesquisa, museus e bibliotecas em entidades privadas. Nas palavras de Carlos Antônio Morales, "são organizações sem fins lucrativos que promovem atividades relacionadas com os direitos sociais dos cidadãos e que expressam a vitaliciedade da sociedade civil ao ocupar os espaços vazios deixados pelo mercado e o Estado." 14

Essas novas entidades foram constituídas para que haja maior qualidade e eficiência nas atividades que serão desempenhadas por elas, com um custo menor ao cidadão. Desse modo, há uma maior autonomia e, consequentemente, maior responsabilidade por parte dos dirigentes das OS, assim como, maior controle social, devido ao contexto de valorização da

\footnotetext{
${ }^{12}$ CARVAlHo FILHO, José dos Santos. Manual de Direito Administrativo. 24a. ed. Rio de Janeiro: Lumen Juris, 2011, p. 327.

${ }^{13}$ ALEXANDRINO, Marcelo. Direito Administrativo Descomplicado. 20a. ed. São Paulo: Método, 2012, p. 146.

${ }^{14}$ MORALES, Carlos Antônio. Provisão de serviços sociais através de organizações públicas não-estatais. In: BRESSER PEREIRA, Luiz Carlos. O público não-estatal na reforma do Estado. Rio de Janeiro; Fundação Getúlio Vargas, 1999. P. 53.
} 
sociedade civil.

A qualificação de OS surgiu como resultado da conversão da Medida Provisória $n^{\circ} 1.648 / 98$ na Lei $n^{\circ}$ 9.637, de 15 de maio de 1998. Trata-se de Pessoa Jurídica de Direito Privado, sem fins lucrativos, criada pela iniciativa privada, para atuação em atividades não exclusivas do Estado, quais sejam: pesquisa, ensino, cultura, saúde e preservação do meio ambiente.

O vínculo jurídico entre a OS e o Estado é feito por iniciativa do Poder Executivo, mediante a celebração de contrato de gestão. Este contrato deve definir critérios de avaliação do desempenho da OS, metas, prazos de execução, dotação orçamentária, permissão de bens públicos.

As organizações sociais não possuem sede própria e se instalam dentro de repartições públicas; os servidores públicos que prestam serviços a essas entidades têm seus salários complementados pelas próprias OS. ${ }^{15}$

A Lei $n^{0}$ 9.637/98 é criticada, basicamente, pela (i) ausência de critérios claros para habilitação das OS, sendo tal ato discricionário, diferentemente do que ocorre com as OSCIP; (ii) inexistência de limites salariais para remuneração dos servidores com recursos públicos; e pela (iii) ausência de exigência da licitação para a celebração do contrato de gestão.

\section{4 - Observações acerca da Lei $9.637 / 98$}

Marçal Justen Filho esclarece que a Organização Social consiste em:

Uma associação civil sem fim lucrativo ou fundação que, em virtude do preenchimento de certos requisitos legais, é submetida a um regime jurídico especial, que contempla benefícios especiais do Estado para execução de determinadas atividades de interesse coletivo. ${ }^{16}$

\footnotetext{
${ }^{15}$ DI PIETRO, Maria Sylvia Zanella. A defesa do cidadão e da res publica. Revista do Serviço Público, Brasília: ENAP, Ano 49, número 2, 1998, p. 128.

${ }^{16}$ JUSTEN FILHO, Marçal. Op. cit., p. 132.
} 
$\mathrm{O}$ art. $1^{\circ}$ da Lei da Lei $\mathrm{n}^{\circ} 9.637 / 98$, por sua vez, especifica que tais entidades serão "dirigidas ao ensino, à pesquisa, científica, ao desenvolvimento tecnológico, à proteção e preservação do meio ambiente, à cultura è̀ saúde".

Para receber o título de Organização Social é preciso respeitar os requisitos previstos no art. $2^{\circ}$ da referida Lei, que, em síntese, são: não possuir finalidade lucrativa; se submeter ao controle do Tribunal de Contas por receber recursos públicos; buscar um fim de interesse público; ter órgãos diretivos colegiados; dar publicidade aos seus atos; e celebrar contrato de gestão.

Cabe salientar que o contrato de gestão é, na verdade, um acordo operacional entre a Administração e a entidade privada, conforme Hely Lopes Meirelles expõe em sua obra. ${ }^{17}$ Além disso, seu objeto será pautado apenas em atividades que tanto poderiam ser desempenhadas pelo Estado como pela iniciativa privada, os chamados serviços sociais.

As atribuições, os critérios de avaliação de desempenho, as metas, as obrigações e as responsabilidades das OS serão definidos no próprio contrato de gestão. A execução deste contrato, a seu turno, será supervisionada pelo órgão ou entidade supervisora da área de atuação da atividade escolhida, por meio de uma comissão supervisora. Esta comissão será formada por especialistas indicados pela autoridade supervisora para elaborar relatório, baseado em um comparativo entre metas e resultados alcançados pela organização social, resultando no cumprimento ou não do contrato de gestão pela organização social, segundo o art. $8^{\circ}$ da Lei das OS. $^{18}$

\footnotetext{
${ }^{17}$ MEIRELLES, Hely Lopes. Direito Administrativo Brasileiro. 26a. ed. São Paulo: Malheiros Editores, 2001, p. 356.

${ }^{18}$ Lei Federal 9637, de 15 de maio de 1998. Art. $8^{\circ}$ A execução do contrato de gestão celebrado por organização social será fiscalizada pelo órgão ou entidade supervisora da área de atuação correspondente à atividade fomentada.
} 
Qualquer irregularidade ou ilegalidade por parte da OS deve ser levada ao conhecimento do Tribunal de Contas da União, sob pena de responsabilidade solidária dos agentes que fiscalizam e dos dirigentes da OS, conforme o art. $9^{\circ}$ da Lei das OS. ${ }^{19}$

A OS deve publicar regulamento próprio, no prazo de 50 dias, contados da assinatura do contrato de gestão. Tal regulamente conterá disposições sobre a contratação de obras, serviços e compras, demonstrando o emprego dos subsídios a ela destinados.

Com a devida qualificação como entidade de interesse social e de utilidade pública, o regime especial da OS estabelece o direito a percepção de subsídios públicos (art. 12, caput e p. $1^{\mathrm{o}}$ e $2^{\circ}$ da Lei das OS), ${ }^{20}$ a utilização gratuita de bens (art. 12 , caput e p. $3^{\circ}$ da Lei da OS) ${ }^{21}$ e a cessão de servidores com ônus para o Estado (art. 14 da Lei das OS). ${ }^{22}$ Isso ocorre

$\S 1^{\circ}$ A entidade qualificada apresentará ao órgão ou entidade do Poder Público supervisora signatária do contrato, ao término de cada exercício ou a qualquer momento, conforme recomende o interesse público, relatório pertinente à execução do contrato de gestão, contendo comparativo específico das metas propostas com os resultados alcançados, acompanhado da prestação de contas correspondente ao exercício financeiro.

$\S 2^{\circ}$ Os resultados atingidos com a execução do contrato de gestão devem ser analisados, periodicamente, por comissão de avaliação, indicada pela autoridade supervisora da área correspondente, composta por especialistas de notória capacidade e adequada qualificação.

$\S 3^{\circ}$ A comissão deve encaminhar à autoridade supervisora relatório conclusivo sobre a avaliação procedida.

${ }^{19}$ Lei Federal 9637, de 15 de maio de 1998. Art. 9ํㅡㄹ Os responsáveis pela fiscalização da execução do contrato de gestão, ao tomarem conhecimento de qualquer irregularidade ou ilegalidade na utilização de recursos ou bens de origem pública por organização social, dela darão ciência ao Tribunal de Contas da União, sob pena de responsabilidade solidária.

${ }^{20}$ Lei Federal 9637, de 15 de maio de 1998. Art. 12. Às organizações sociais poderão ser destinados recursos orçamentários e bens públicos necessários ao cumprimento do contrato de gestão.

$\S 1^{\circ}$ São assegurados às organizações sociais os créditos previstos no orçamento e as respectivas liberações financeiras, de acordo com o cronograma de desembolso previsto no contrato de gestão. $\S 2^{\mathrm{o}}$ Poderá ser adicionada aos créditos orçamentários destinados ao custeio do contrato de gestão parcela de recursos para compensar desligamento de servidor cedido, desde que haja justificativa expressa da necessidade pela organização social.

$\S 3^{-}$Os bens de que trata este artigo serão destinados às organizações sociais, dispensada licitação, mediante permissão de uso, consoante cláusula expressa do contrato de gestão.

${ }^{21}$ Lei Federal 9637, de 15 de maio de 1998. Ibid., art. 12.

${ }^{22}$ Lei Federal 9637, de 15 de maio de 1998. Art. 14. É facultado ao Poder Executivo a cessão especial de servidor para as organizações sociais, com ônus para a origem.

$\S 1^{\mathrm{o}}$ Não será incorporada aos vencimentos ou à remuneração de origem do servidor cedido qualquer vantagem pecuniária que vier a ser paga pela organização social.

$\S 2^{\circ}$ Não será permitido o pagamento de vantagem pecuniária permanente por organização social a servidor cedido com recursos provenientes do contrato de gestão, ressalvada a hipótese de adicional relativo ao exercício de função temporária de direção e assessoria. 
devido à autonomia financeira e administrativa que lhe foi conferida, observadas as condições dispostas na lei específica.

Insta salientar que, conforme contexto ora assinalado, existe uma intensa participação social na busca da prestação de serviços públicos de forma mais eficiente, o que, consequentemente, importa em uma maior fiscalização dos dirigentes dessas entidades privadas. Estes, por sua vez, passam a ter maior responsabilidade pelos atos praticados na gestão da OS.

Caso queiram se utilizar dessa forma de parceria, os Estados e Municípios devem aprovar suas próprias leis, tendo em vista que a Lei das OS não é nacional, não se aplicando, portanto, a todos os entes federativos. Com efeitos, tal Lei apenas serve de modelo para as demais, devidamente adequadas conforme as peculiaridades de cada região.

Para haver a desqualificação da entidade privada é necessária a comprovação de que houve descumprimento do conteúdo do contrato de gestão, sendo que o processo administrativo que pretenda ensejar tal desqualificação deverá sempre observar a ampla defesa e o contraditório, de acordo com o art. $5^{\circ}$, LX da $\mathrm{CF}$. O mesmo se diga com relação ao julgamento dos dirigentes da OS em questão.

Em caso de desqualificação de determinada OS, ocorrerá a reversão dos bens e dos recursos à Fazenda Pública, assim como a, responsabilização dos dirigentes da organização social de forma solidária, nos termos dos artigos 16 a 18 da Lei das OS. ${ }^{23}$

$\S 3^{\circ} \mathrm{O}$ servidor cedido perceberá as vantagens do cargo a que fizer jus no órgão de origem, quando ocupante de cargo de primeiro ou de segundo escalão na organização social.

${ }^{23}$ Lei Federal 9637, de 15 de maio de 1998.Art. 16. O Poder Executivo poderá proceder à desqualificação da entidade como organização social, quando constatado o descumprimento das disposições contidas no contrato de gestão.

$\S 1^{\mathrm{o}} \mathrm{A}$ desqualificação será precedida de processo administrativo, assegurado o direito de ampla defesa, respondendo os dirigentes da organização social, individual e solidariamente, pelos danos ou prejuízos decorrentes de sua ação ou omissão.

$\S 2^{-}$A desqualificação importará reversão dos bens permitidos e dos valores entregues à utilização da organização social, sem prejuízo de outras sanções cabíveis. 
As primeiras Organizações Sociais estão previstas no Anexo I da Lei n 9.637/98, quais sejam: Associação de Comunicação Educativa Roquette Pinto e Associação Brasileira de Tecnologia de Luz Síncroton.

Diante do exposto, verifica-se a criação da Lei das OS possibilita que tais entidades prestem as atividades supramencionadas, restando ao Estado a atividade de fomento.

Nesse contexto, confira-se a transcrição da ementa de precedente do Tribunal de Justiça do Distrito Federal:

EMBARGOS INFRINGENTES EM APELAÇÃO CÍVEL. CONTRATO DE GESTÃO (ICS E SLU). OBJETO DA CONTRATAÇÃO. SERVIÇOS DE LIMPEZA URBANA. HIPÓTESE NÃO CONTEMPLADA NA LEI DISTRITAL N. 2.177/98. INVALIDADE DO CONTRATO. - A CONSTITUIÇÃO FEDERAL PREVÊ A CELEBRAÇÃO DE CONTRATOS DE GESTÃO PELA ADMINISTRAÇÃO PÚBLICA, COM ENTIDADES DO SETOR PRIVADO, DENOMINADAS ORGANIZAÇÕES SOCIAIS (ART. 37, $\S 8^{\circ}$ ), SENDO POSSÍVEL A DISPENSA DO PROCESSO LICITATÓRIO "PARA A CELEBRAÇÃO DE CONTRATOS DE PRESTAÇÃO DE SERVIÇOS COM AS ORGANIZAÇÕES SOCIAIS, QUALIFICADAS NO ÂMBITO DAS RESPECTIVAS ESFERAS DE GOVERNO, PARA ATIVIDADES CONTEMPLADAS NO CONTRATO DE GESTÃO" (ART. 24, INC. XXIV, DA LEI DE LICITAÇÕES). - O OBJETO DO CONTRATO DE GESTÃO EM TELA, ESPECIFICADO COMO "COLETA E TRANSPORTE DE LIXO DOMÉSTICO, COMERCIAL E HOSPITALAR; REMOÇÃO DE ENTULHOS; VARRIÇÃO; CATAÇÃO DE PAPÉIS; CAPINA; DESTINAÇÃO FINAL; RECICLAGEM E COMPOSTAGEM; PINTURA DE MEIOS-FIOS; LAVAGEM DE LOGRADOUROS", NÃO SE AMOLDA AOS DITAMES DA LEI N. 2177/98, QUE INTRODUZIU A FIGURA DO CONTRATO DE GESTÃO AO ORDENAMENTO JURÍDICO DISTRITAL E IMPÕE, EM SEU ART. $3^{\circ}$, A PRESTAÇÃO DE SERVIÇOS PÚBLICOS RELACIONADOS A ATIVIDADES "VOLTADAS AO ENSINO, À PESQUISA CIENTÍFICA, AO DESENVOLVIMENTO TECNOLÓGICO, À PROTEÇÃO E PRESERVAÇÃO DO MEIO AMBIENTE, À DEFESA DO CONSUMIDOR, À CULTURA E À SAÚDE". - EVIDENCIADA A IRREGULARIDADE DO CONTRATO NO OBJETO DA PARCERIA ENTRE O PODER PÚBLICO E A ORGANIZAÇÃO SOCIAL, REVELAM-SE VICIADOS TODOS OS SEUS DESDOBRAMENTOS, COMO A INEXISTÊNCIA DE LICITAÇÃO PARA A PRESTAÇÃO DO

Lei Federal 9637/98. Art. 17. A organização social fará publicar, no prazo máximo de noventa dias contado da assinatura do contrato de gestão, regulamento próprio contendo os procedimentos que adotará para a contratação de obras e serviços, bem como para compras com emprego de recursos provenientes do Poder Público.

Lei Federal 9637/98. Art. 18. A organização social que absorver atividades de entidade federal extinta no âmbito da área de saúde deverá considerar no contrato de gestão, quanto ao atendimento da comunidade, os princípios do Sistema Único de Saúde, expressos no art. 198 da Constituição Federal e no art. $7^{\circ}$ da Lei ${ }^{\circ} 8.080$, de 19 de setembro de 1990. 
SERVIÇO E A CONTRATAÇÃO DE PESSOAL SEM CONCURSO PÚBLICO. EMBARGOS INFRINGENTES PROVIDOS. MAIORIA. ${ }^{24}$

No que concerne às criticas a Lei das OS, a doutrina questiona o poder discricionário dado, pela Lei $n^{\circ} 9.637 / 98$, ao administrador público para a escolha da entidade que receberá a qualificação das organizações sociais, visto que a falta de clareza acerca dos critérios que as criam podem resultar em fraude à lei ou arbítrio do Poder Público. Nota-se o desrespeito ao princípio constitucional da impessoalidade e da isonomia entre os possíveis interessados.

Na realidade, o exame que conferirá a qualificação a uma certa OS é feito de acordo com critérios de conveniência e oportunidade pelo Ministério da área da atividade constante no objeto social da entidade. No entanto, frise-se que, a outorga ou não do título de OS deve ser motivada, ou seja, precisa estar baseada no interesse público que a consubstancia.

A doutrina majoritária ${ }^{25}$ entende que a Organização Social exerce atividade de natureza privada, apenas com incentivo público e que, por essa razão, a atuação perante terceiros é regida pelo direito privado. Para esses autores, a percepção de recursos, a cessão de bens e servidores não fazem dessa entidade integrante da Administração Pública.

Entretanto, Maria Sylvia Zanella Di Pietro entende que as OS são entidades de colaboração, que possuem, porém a peculiaridade de, em regra geral, desenvolver serviço público delegado pelo Poder Público. A principal decorrência do entendimento desta autora é que, por se tratar de delegação de serviço público, a responsabilidade civil da entidade seria objetiva, nos moldes do art. $37, \S 6^{\circ}$ da Constituição Federal. ${ }^{26}$

\footnotetext{
${ }^{24}$ BRASIL. Tribunal de Justiça do Distrito Federal-DF. Embargos infringentes em apelação ${ }^{\circ}$ 0091469-95.1999.807.0001. Relator: Otávio Augusto. Órgão Julgador: $1^{\text {a }}$ Câmara Cível. Julgamento: 20.11.06, Publicação: 30.11.06, p. 118.

${ }^{25}$ JUSTEN FILHO, Marçal. Op. cit., p. 132.

${ }^{26}$ DI PIETRO, Maria Sylvia Zanella. Direito Administrativo. 25a ed. São Paulo: Atlas, 2012, p. 553 e 554.
} 
A partir desse entendimento, a autora sustenta ainda que o Estado limita-se a incentivar apenas a iniciativa privada através dessa parceira, deixando de prestar certos serviços na área social. Em seus termos: "pela forma como a matéria está disciplinada na esfera federal, são inegáveis o conteúdo de imoralidade contido na lei, os riscos para o patrimônio público e para os direitos do cidadão., ${ }^{27}$

Para a referida autora, a finalidade da OS é mascarar uma situação de direito público com a roupagem de entidade privada, já que há utilização do patrimônio e de servidores públicos. Logo, viverão exclusivamente por causa do contrato de gestão.

Ademais, é do mesmo modo bastante questionada a ausência de limitações à remuneração dos empregados dessas entidades, uma vez que os servidores públicos possuem um teto constitucional.

No que tange as licitações, o art. 24, XXIV da Lei ${ }^{0}$ 8.666/93 dispensa licitação para a "celebração de contratos de prestações de serviços com as Organizações Sociais, qualificadas no âmbito das respectivas esferas de governo, para atividades contempladas no contrato de gestão."

Sobre estes aspectos, Maria Sylvia Zanella Di Pietro ${ }^{28}$ sustenta que a lei precisaria conter a exigência de licitação para qualificação em OS, qualificação técnica e idoneidade financeira para gerir recurso público, imposição de limitação salarial, prestação de garantia e comprovação de patrimônio, sede próprios como exigidos para formação de uma pessoa jurídica.

Salienta-se que o procedimento da licitação será objeto de estudo do próximo capítulo.

\footnotetext{
${ }^{27}$ DI PIETRO, Maria Sylvia Zanella. Parcerias na Administração Pública: concessão, permissão, franquia, terceirização, parceria público-privada e outras formas. 8a.ed.. São Paulo: Atlas, 2011, p. 269.

${ }^{28}$ Ibid. p. 271.
} 


\section{CAPÍTULO 3 - O PODER PÚBLICO E O DEVER DE LICITAR}

\section{1 - Definição de licitação}

A licitação é um procedimento administrativo que estabelece critérios objetivos para seleção da proposta mais vantajosa, podendo ser disciplinado por lei ou por ato administrativo prévio, desde que em observância ao princípio da isonomia e autorizado por uma autoridade competente. ${ }^{29}$

José dos Santos Carvalho Filho conceitua licitação como "um procedimento administrativo vinculado por meio do qual os entes de Administração Pública e aqueles por ela controlados selecionam a melhor proposta entre as oferecidas pelos vários interessados, com dois objetivosa celebração de contrato, ou a obtenção do melhor trabalho técnico, artístico ou cientifico. ${ }^{, 30}$

Diante desses conceitos, define-se licitação como o procedimento administrativo pelo qual a Administração Pública abre a todos os interessados, observada a igualdade entre eles e respeitadas as condições impostas no instrumento convocatório, a possibilidade de apresentarem suas propostas dentre as quais será selecionada a mais vantajosa aos interesses da Administração.

O procedimento licitatório diminui a liberdade de escolha do Poder Público, na medida em que seu resultado final não depende da decisão discricionária do administrador. A licitação é qualificada como sendo vinculada, pois utiliza-se de critérios objetivos, previamente estipulados no instrumento convocatório.

\footnotetext{
${ }^{29}$ JUSTEN FILHO, Marçal. Curso de direito administrativo. São Paulo: Saraiva, 2005. p. 309.

${ }^{30}$ CARVAlHO FILHO, José dos Santos. Manual de Direito Administrativo. 24a. ed. Rio de Janeiro: Lumen Juris, 2011, p. 218.
} 
$\mathrm{O}$ ato de convocação estabelece o objeto, regras de julgamento, requisitos de seleção do vencedor e critérios de participação. Tais critérios devem ser assistidos ao longo de todo o procedimento, tanto pelos administrados como pelos administradores.

Não obstante, o referido certame garante maior segurança aos particulares que resolvem participar, uma vez que propicia igual oportunidade aos mesmos, resguardando, ainda, os direitos dos possíveis contratados.

Note-se que a seleção da proposta mais vantajosa para a Administração Pública deve estar pautada na realização de prestação menos onerosa e mais completa, buscando-se, com a licitação, o denominado o binômio qualidade-onerosidade, que contempla dois aspectos fundamentais: o menor custo e o maior benefício para a sociedade.

Percebe-se, assim, que o procedimento de licitação estabelece como finalidades: a obtenção da proposta que melhor atende aos interesses da administração e a igualdade entre os participantes.

Importante salientar que é necessário que o procedimento seja conduzido por um órgão competente. Na maioria dos casos, será designada uma comissão permanente, composta por, no mínimo, três membros, dentre os quais dois serão servidores efetivos, a teor do disposto no art. 51 da Lei $n^{\circ} 8666 / 93$. $^{31}$

\footnotetext{
${ }^{31}$ Cf. art. 51 da Lei n. 8.6666/93.A habilitação preliminar, a inscrição em registro cadastral, a sua alteração ou cancelamento, e as propostas serão processadas e julgadas por comissão permanente ou especial de, no mínimo, 3 (três) membros, sendo pelo menos 2 (dois) deles servidores qualificados pertencentes aos quadros permanentes dos órgãos da Administração responsáveis pela licitação.

$\S 1$ o No caso de convite, a Comissão de licitação, excepcionalmente, nas pequenas unidades administrativas e em face da exiguidade de pessoal disponível, poderá ser substituída por servidor formalmente designado pela autoridade competente.

§ 20 A Comissão para julgamento dos pedidos de inscrição em registro cadastral, sua alteração ou cancelamento, será integrada por profissionais legalmente habilitados no caso de obras, serviços ou aquisição de equipamentos.
} 
No que concerne à disciplina constitucional, a competência para licitar está prevista no artigo 22, XXII da Constituição Federal, senão vejamos:

Art. 22. Compete privativamente à União legislar sobre:

XXVII - normas gerais de licitação e contratação, em todas as modalidades, para as administrações públicas diretas, autárquicas e fundacionais da União, Estados, Distrito Federal e Municípios, obedecido o disposto no art. 37, XXI, e para as empresas públicas e sociedades de economia mista, nos termos do art. 173, § $1^{\circ}$, III; (Redação dada pela Emenda Constitucional n ${ }^{\circ}$ 19, de 1998).

O texto constitucional também manifestou a obrigatoriedade da licitação, não podendo o Poder Público renunciar deste certame, salvo nas hipóteses previstas em lei, nos termos do art. 37, XXI:

Art. 37. A administração pública direta e indireta de qualquer dos Poderes da União, dos Estados, do Distrito Federal e dos Municípios obedecerá aos princípios de legalidade, impessoalidade, moralidade, publicidade e eficiência e, também, ao seguinte: (Redação dada pela Emenda Constitucional nº 19, de 1998)

XXI - ressalvados os casos especificados na legislação, as obras, serviços, compras e alienações serão contratados mediante processo de licitação pública que assegure igualdade de condições a todos os concorrentes, com cláusulas que estabeleçam obrigações de pagamento, mantidas as condições efetivas da proposta, nos termos da lei, o qual somente permitirá as exigências de qualificação técnica e econômica indispensáveis à garantia do cumprimento das obrigações. (Regulamento).

Outrossim, em sede constitucional, o art. 173, $\S 1^{\circ}$, III dispõe sobre a licitação em relação as empresas públicas e sociedades de economia mista. $^{32}$

No que tange à disciplina legal acerca de licitação, a lei que a regula é a Lei $n^{\circ} 8.666$, de 21 de junho de 1993. Tal Lei é considerada como o estatuto geral das licitações, autorizado pelo enunciado constitucional, sendo composto por normas gerais, que disciplinam, por exemplo, princípios, vedações a outros entes federativos, modalidades, limites e etc.

\footnotetext{
${ }^{32}$ Constituição Federal. Art 173, $\S 1$, III. Ressalvados os casos previstos nesta Constituição, a exploração direta de atividade econômica pelo Estado só será permitida quando necessária aos imperativos da segurança nacional ou a relevante interesse coletivo, conforme definidos em lei. $\S 1^{\circ} \mathrm{A}$ lei estabelecerá o estatuto jurídico da empresa pública, da sociedade de economia mista e de suas subsidiárias que explorem atividade econômica de produção ou comercialização de bens ou de prestação de serviços, dispondo sobre: (Redação dada pela Emenda Constitucional ${ }^{\circ}{ }^{19}$, de 1998)

III - licitação e contratação de obras, serviços, compras e alienações, observados os princípios da administração pública; (Incluído pela Emenda Constitucional nº 19, de 1998)
} 


\section{2 - Princípios norteadores da licitação.}

O procedimento licitatório deve ser pautado em alguns princípios básicos expressos no art. $3^{\circ}$ da Lei $n^{\circ} 8666 / 93$, dentre os quais se destacam os princípios da: legalidade, impessoalidade, impessoalidade, publicidade, probidade administrativa, vinculação ao instrumento convocatório e julgamento objetivo, brevemente analisados a seguir:

\subsection{1 - Princípio da legalidade}

O princípio da legalidade significa que a atuação do administrador deve ser pautada no que a lei impõe, sendo indiferente a sua vontade pessoal. No que tange à licitação, este princípio obriga que a Administração Pública observe as regras e condições estipuladas previamente em lei. ${ }^{33}$

\subsection{2 - Princípio da impessoalidade e isonomia}

Entende-se que o administrador deve dispensar idêntico tratamento a todos os administrados. Isto é, os participantes devem competir em igualdade de condições, sendo vedada qualquer tipo de vantagem ou discriminação injustificada. ${ }^{34}$

Este princípio informa a busca por um tratamento impessoal ao assegurar a prerrogativa de que todos possuem iguais expectativas de realizar contratação com o Poder Público.

\footnotetext{
${ }^{33}$ GARCIA, Flávio Amaral. Licitações e contratos administrativos. 2a. ed. Rio de Janeiro: Lumen Juris, 2009, p. 4.

34 ARAGÃO, Alexandre Santos de. Curso de direito administrativo. 1a. ed. Rio de Janeiro: Forense, 2012, p. 290.
} 
No que se refere ao procedimento licitatório, portanto, tal princípio possui duas vertentes: (i) todos os participantes devem ser tratados de forma isonômica na disputa; e (ii) deve ser dada oportunidade de participação na licitação a qualquer interessado que tenha condições de contratar com a administração.

\subsection{3 - Princípio da publicidade}

Este princípio sustenta que a licitação deve ser amplamente divulgada, de modo a facilitar o conhecimento de maior número de pessoas e tornar a seleção mais eficaz. ${ }^{35}$

Além disso, tem como objetivo o acompanhamento e fiscalização do procedimento, não só pelos licitantes e pelo administrador, como também pela sociedade em geral, assegurando-se, deste modo, uma licitação transparente. Havendo maior conhecimento acerca do certame, será possível, consequentemente, majorar o número de participantes, propiciando uma seleção mais qualificada.

\subsection{4 - Princípio da probidade e moralidade administrativa}

Significa que o agente administrativo deve agir de forma honesta e ética, em todo o procedimento licitatório tanto no trato com os participantes quanto com a própria Administração Pública. Exige-se que administrador esteja voltado ao interesse administrativo, promovendo a seleção da melhor proposta, independentemente de sua opinião pessoal, sob pena de responsabilização nas esferas penal, civil e administrativa. ${ }^{36}$

\footnotetext{
35 ALEXANDRINO, Marcelo. Direito administrativo descomplicado. 20a. ed. Rio de Janeiro: Forense, 2012, p. 578.

${ }^{36}$ Ibid. p. 591.
} 
Ressalta-se que alguns doutrinadores sustentam que o princípio da moralidade também é aplicado ao comportamento dos participantes da licitação e não só ao administrador.

\subsection{5 - Princípio da vinculação ao instrumento convocatório}

Tal princípio informa que as regras estabelecidas previamente na licitação não podem ser descumpridas por parte do agente administrativo, o que consiste na segurança de que os termos do instrumento convocatório não serão alterados ao longo do certame, sob pena de se tornar inválido. ${ }^{37}$

Nas palavras de Hely Lopes Meirelles, o edital é "a lei interna da licitação”. ${ }^{38} \mathrm{O}$ art. 41 da Lei 8.666/93 prevê que o administrador não pode descumprir as normas e condições do edital, ao qual se acha estritamente vinculado.

Ademais, a observância desse princípio evita que haja violação à moralidade ou até mesmo que haja fraude no procedimento. $\mathrm{O}$ instrumento convocatório é exteriorizado por meio de edital. Caso este precise ser corrigido, é necessário que tal mudança seja conhecida pelos licitantes, nos moldes do art. $21, \S 4^{\text {o }}$ do Estatuto Geral de licitação. ${ }^{39}$

\subsection{6 - Princípio do julgamento objetivo}

Traduz a ideia de que o critério indicado no edital não pode ser afastado durante o procedimento licitatório, evitando-se, assim, qualquer

\footnotetext{
${ }^{37}$ GARCIA, Flávio Amaral. Op. cit., p. 6.

${ }^{38}$ MEIRELLES, Hely Lopes. Direito Administrativo Brasileiro. São Paulo: Malheiros Editores, 2001, p. 259.

${ }^{39}$ Lei. $8666 / 93$. Art $21, \S 4^{\circ}$.Qualquer modificação no edital exige divulgação pela mesma forma que se deu o texto original, reabrindo-se o prazo inicialmente estabelecido, exceto quando, inquestionavelmente, a alteração não afetar a formulação das propostas.
} 
surpresa para os licitantes, nos termos do art. 45 da lei supramencionada. ${ }^{40}$ A observância deste princípio tem o condão de afastar a discricionariedade na apreciação das propostas. ${ }^{41}$

\subsection{7 - Princípio do procedimento formal}

Cabe salientar que este princípio não se encontra elencado no art. $3^{\circ} \mathrm{da}$ Lei 8.666/93, estando, na realidade, conjecturado no art. $4^{\circ}$, $\S$ único da mesma lei, qual seja: "o procedimento licitatório previsto nesta lei caracteriza ato administrativo formal, seja ele praticado em qualquer esfera da Administração Pública."

Segundo Hely Lopes Meirelles ${ }^{42}$, trata-se de princípio cardeal das licitações, sendo definido como aquele que "impõe a vinculação da licitação às prescrições legais que a regem em todos os seus atos e fases".

\subsection{8 - Sigilo na apresentação das propostas}

A maior parte da doutrina brasileira também inclui o sigilo na apresentação das propostas como um princípio a ser observado no âmbito das licitações. ${ }^{43}$

Em verdade, este deriva do princípio da igualdade entre os licitantes, uma vez que o proponente que souber antecipadamente das propostas dos outros concorrentes, estará em uma posição favorável no momento de apresentar a sua. Por este motivo, todas as propostas somente serão

\footnotetext{
${ }^{40}$ Lei 8.666/93. Art. 45. O julgamento das propostas será objetivo, devendo a Comissão de licitação ou o responsável pelo convite realizá-lo em conformidade com os tipos de licitação, os critérios previamente estabelecidos no ato convocatório e de acordo com os fatores exclusivamente nele referidos, de maneira a possibilitar sua aferição pelos licitantes e pelos órgãos de controle.

${ }^{41}$ ARAGÃO, Alexandre Santos de. Op. cit., p. 292.

${ }^{42}$ MEIRELLES, Hely Lopes. Op. cit., p. 257.

${ }^{43}$ Ibid. p. 258.
} 
conhecidas na data designada para a abertura dos envelopes, sob pena de invalidação do certame.

\section{3 - Considerações gerais sobre a Lei 8.666/93.}

$\mathrm{O}$ objeto da licitação pode ser dividido em mediato e imediato. $\mathrm{O}$ mediato consiste na obtenção de compra, serviço, alienação, obra, concessão, permissão ou prestação de serviço público a serem produzidos por particulares através de um contrato com o Poder Público. O objeto imediato, a seu turno, trata da seleção da proposta mais vantajosa aos interesses da Administração.

O aludido certame tem caráter instrumental, porquanto espelha um meio para que a Administração alcance o fim por ela colimado. ${ }^{44}$ Logo, a finalidade da licitação é sempre a obtenção do objeto da melhor forma para a Administração Pública. A licitação que não caracteriza o objeto pretendido é nula, ou seja, é a condição de legitimidade do procedimento licitatório.

Outro aspecto relevante na Lei $\mathrm{n}^{0} 8.666 / 93$ é em relação à obrigatoriedade de licitação de obras, serviços, compras e alienações para toda a Administração Pública, direta ou indireta, salvo as hipóteses previstas em lei, assim como, para a concessão e permissão de serviços públicos, segundo art. 175 da CF.

Nas palavras de Hely Lopes Meirelles: ${ }^{45}$

A expressão obrigatoriedade de licitação tem um duplo sentido, significando não só a compulsoriedade da licitação em geral, como, também, a modalidade prevista em lei para a espécie, pois atenta contra os princípios da moralidade e eficiência da Administração o uso da modalidade mais singela quando se exige a mais complexa, ou o emprego desta, normalmente mais onerosa, quando o objeto do procedimento licitatório não a comporta. Somente a lei pode desobrigar a Administração, quer

\footnotetext{
${ }^{44}$ CARVALHO FILHO, José dos Santos. Op. cit., p. 223.

${ }^{45}$ MEIRELLES, Hely Lopes. Op. cit., p. 262.
} 
autorizando a dispensa de licitação, quando exigível, quer permitindo a substituição de modalidade por outra.

No que tange à inaplicabilidade da Lei Geral de licitações nas contratações com o Terceiro Setor, o Tribunal de Contas da União ${ }^{46}$ exige apenas a edição de regulamentos próprios, contendo os princípios gerais da licitação, com base nos arts. 17 da Lei no $9.637 / 99$ e 14 da Lei no 9.790/99.

Insta salientar que o Decreto $\mathrm{n}^{0} 5.504$ de 2005 estipulou que os instrumentos de convênios e de consórcios públicos que tenham repasse de subsídios públicos da União devem determinar que as compras, obras e serviços a serem desenvolvidos por esses entes privados ou públicos, sejam contratados através de licitação. Dessa forma, a interpretação que se fez foi a de que o Terceiro Setor como um todo, por ser composto por entidades privadas, deveria se submeter à lei geral de licitação pública.

O art. 11 do Decreto ${ }^{\circ} 6.170$ de 2007, por sua vez, estabeleceu que a aquisição de produtos e a contratação de serviços com recursos da União transferidos a entidades privadas sem fins lucrativos deverão observar os princípios da impessoalidade, moralidade e economicidade, sendo necessária, no mínimo, a realização de cotação prévia de preços no mercado antes da celebração do contrato.

Diante dessa leitura, nota-se que o Decreto $\mathrm{n}^{0} \quad 5.504 / 05$ foi parcialmente revogado. ${ }^{47}$ Ocorre que ambos os decretos mencionados desrespeitam as Leis $n^{\circ} 9.637 / 98$ e 9.790/99, uma vez que estas exigem regulamentos próprios elaborados pelas entidades, e não pelo Executivo, o que torna sua legalidade é questionável. Sendo assim, afasta-se a obrigatoriedade de licitação para as entidades privadas sem fins lucrativos, como é das entidades que compõem o Terceiro Setor.

\footnotetext{
${ }^{46}$ BRASIL. Tribunal de Contas da União. Decisão no 907/07. Plenário. Ata n ${ }^{\circ}$ 53/97.

47 MADAUAR, Odete. Direito Administrativo Moderno. 13a. ed. São Paulo: Revista dos Tribunais, 2009, pp. 101-103.
} 
Rafael Oliveira ${ }^{48}$ defende que o repasse de recursos públicos deve ser realizado de acordo com os princípios constitucionais e administrativos, até que sejam criados os regulamentos de cada entidade.

A Lei $\mathrm{n}^{\mathrm{0}}$ 8.666/93 ressalvou algumas hipóteses que não se compatibilizam com a demora e o rito da licitação. Com efeito, há na lei, hipóteses de dispensa de licitação, conforme a peculiaridade de cada caso, o que implica na contratação pela via direta.

Fica claro, portanto, que mesmo sem realizar a licitação, a contratação direta não afasta a observância dos princípios constitucionais da impessoalidade, legalidade, motivação, moralidade, eficiência e publicidade

No que concerne à dispensa de licitação, a lei permitiu que em alguns casos o administrador pode ou deve deixar de realizá-la, tornando-a dispensada, dispensável ou inexigível. A licitação dispensada é aquela que a Administração Pública não poderá realizar o procedimento licitatório e a própria lei declarou como assim sendo, conforme o art. 17 da Lei $\mathrm{n}^{\circ}$ 8.666/93. ${ }^{49}$ Tratam-se de hipóteses taxativas, como, por exemplo, na alienação de bens públicos e dominicais.

\footnotetext{
${ }^{48}$ OLIVEIRA, Rafael Carvalho Rezende. Direito Administrativo. 22a. ed. São Paulo: Atlas, 2009, pp. 497-498.

${ }^{49}$ Lei Federal 8.666/93. Art. 17. A alienação de bens da Administração Pública, subordinada à existência de interesse público devidamente justificado, será precedida de avaliação e obedecerá às seguintes normas:

I - quando imóveis, dependerá de autorização legislativa para órgãos da administração direta e entidades autárquicas e fundacionais, e, para todos, inclusive as entidades paraestatais, dependerá de avaliação prévia e de licitação na modalidade de concorrência, dispensada esta nos seguintes casos:

a) dação em pagamento;

b) doação, permitida exclusivamente para outro órgão ou entidade da administração pública, de qualquer esfera de governo, ressalvado o disposto nas alíneas $f, h$ e i; (Redação dada pela Lei $n^{\circ}$ 11.952, de 2009)

c) permuta, por outro imóvel que atenda aos requisitos constantes do inciso X do art. 24 desta Lei;

d) investidura;

e) venda a outro órgão ou entidade da administração pública, de qualquer esfera de governo; (Incluída pela Lei $\mathrm{n}^{\circ} 8.883$, de 1994)

f) alienação gratuita ou onerosa, aforamento, concessão de direito real de uso, locação ou permissão de uso de bens imóveis residenciais construídos, destinados ou efetivamente utilizados no âmbito de programas habitacionais ou de regularização fundiária de interesse social desenvolvidos por órgãos ou entidades da administração pública; (Redação dada pela Lei $n^{0}$ 11.481, de 2007)
} 
Já a inexigibilidade de licitação ocorre quando há impossibilidade de competição entre os licitantes, ${ }^{50}$ tendo em vista que apenas existe uma pessoa ou um objeto que atenda as necessidades do Poder Público. Logo, a licitação é inviável, porém não exonera a administração do dever de motivar. A lei é exemplificativa e traz como exemplos: o caso de fornecedor exclusivo, profissionais de notória especialização e artistas consagrados pela crítica. ${ }^{51}$

Por outro lado, a licitação dispensável é aplicada em certas situações concretas eleitas previamente pelo legislador, nas quais a Administração a dispensa se lhe for conveniente. ${ }^{52}$ A própria lei abre espaço para a discricionariedade do administrador, observado o princípio da razoabilidade, para atender o interesse público. Tais hipóteses estão arroladas em uma lista exaustiva, ${ }^{53}$ sendo relevante para o presente trabalho

g) procedimentos de legitimação de posse de que trata o art. 29 da Lei no 6.383, de 7 de dezembro de 1976, mediante iniciativa e deliberação dos órgãos da Administração Pública em cuja competência legal inclua-se tal atribuição; (Incluído pela Lei no 11.196, de 2005)

h) alienação gratuita ou onerosa, aforamento, concessão de direito real de uso, locação ou permissão de uso de bens imóveis de uso comercial de âmbito local com área de até $250 \mathrm{~m}^{2}$ (duzentos e cinqüenta metros quadrados) e inseridos no âmbito de programas de regularização fundiária de interesse social desenvolvidos por órgãos ou entidades da administração pública; (Incluído pela Lei ${ }^{\circ} 11.481$, de 2007)

i) alienação e concessão de direito real de uso, gratuita ou onerosa, de terras públicas rurais da União na Amazônia Legal onde incidam ocupações até o limite de 15 (quinze) módulos fiscais ou 1.500ha (mil e quinhentos hectares), para fins de regularização fundiária, atendidos os requisitos legais; (Incluído pela Lei $n^{\circ} 11.952$, de 2009)

II - quando móveis, dependerá de avaliação prévia e de licitação, dispensada esta nos seguintes casos:

a) doação, permitida exclusivamente para fins e uso de interesse social, após avaliação de sua oportunidade e conveniência sócio-econômica, relativamente à escolha de outra forma de alienação;

b) permuta, permitida exclusivamente entre órgãos ou entidades da Administração Pública;

c) venda de ações, que poderão ser negociadas em bolsa, observada a legislação específica;

d) venda de títulos, na forma da legislação pertinente;

e) venda de bens produzidos ou comercializados por órgãos ou entidades da Administração Pública, em virtude de suas finalidades;

f) venda de materiais e equipamentos para outros órgãos ou entidades da Administração Pública, sem utilização previsível por quem deles dispõe.

${ }^{50} \mathrm{Cf}$. Lei federal 8.666/93. Art. 25.

${ }^{51}$ GARCIA, Flávio Amaral. Op. cit., p. 41.

${ }^{52}$ Cf. Lei $n^{\circ}$ 8.666/93. Art. 24.

${ }^{53}$ JUSTEN FILHO, Marçal. Op. cit., p. 233. 
o inciso XXIV do art. 24 da Lei 8.666/93, ${ }^{54}$ que será objeto de estudo do próximo capítulo.

Vale ressaltar que o dispositivo em comento traz a exigência de que as atividades que serão desempenhadas sejam do interesse da Administração Pública, e que estejam definidas no contrato de gestão.

Marçal Justen Filho ${ }^{55}$ ensina que a dispensa só será legítima caso a entidade licitante e a OS sejam da mesma esfera de governo. Assim, se a União contrata diretamente uma OS qualificada por um Estado, esta contratação será ilegal, não bastando ser OS para poder dispensar a licitação pública.

Não obstante, o TCU possui o mesmo posicionamento, senão vejamos o Acordão n ${ }^{\circ}$ 421/04 proferido pelo Plenário do referido Tribunal:

Em caso de entidades qualificadas como Organização Social, o TCU respondeu ao consulente que a contratação por dispensa de licitação fundada no art. 24 , inciso XXIV, da Lei $n^{\circ}$ 8.666/1993 submete-se à estrita e simultânea observância dos seguintes requisitos:

a) a pessoa jurídica contratada deve ser qualificada como Organização Social, nos termos da Lei $n^{\circ} \mathbf{9 . 6 3 7 / 9 8}$, por ato formal da esfera de governo à qual pertence o órgão ou entidade contratante;

b) o objeto da contratação deve ser necessariamente a prestação de serviços, tomados na acepção do art. $6^{\circ}$, inciso II, da Lei $n^{\circ}$ 8.666/1993, devendo tais serviços estarem inseridos no âmbito das atividades fins, previstas no seu estatuto e constantes do contrato de gestão firmado entre a Organização Social e o Poder Público, na forma dos arts. $5^{\circ}$ a $7^{\circ}$ da Lei ${ }^{\circ}$ 9.637/98;

c) na hipótese de não estarem preenchidos os requisitos arrolados nas alíneas "a" e "b" supra, não há amparo legal para a realização de contratação por dispensa de licitação fundamentada no art. 24, inciso XXIV, da Lei $n^{\circ}$ 8.666/1993, ainda que existam semelhanças entre o regime jurídico das entidades apresentadas para contratação e o das pessoas jurídicas mencionadas na alínea "a" retro;

d) os Serviços Sociais Autônomos somente poderiam ser contratados por dispensa de licitação com base no art. 24, inciso XXIV, da Lei n ${ }^{\circ}$ 8.666/1993, caso atendam sobretudo aos requisitos contidos nos arts. 2o, 3o e 4o da Lei 9.637/98 e venham a ser formalmente qualificados, por ato do Poder Executivo, como Organizações

\footnotetext{
${ }^{54}$ Lei federal 8.666/93. Art. 24. É dispensável a licitação: XXIV - para a celebração de contratos de prestação de serviços com as organizações sociais, qualificadas no âmbito das respectivas esferas de governo, para atividades contempladas no contrato de gestão.

${ }^{55}$ GASPARINI, Diógenes. Direito Administrativo. 15a. ed. São Paulo: Saraiva, 2010, p. 596.
} 
Sociais nos termos do art. 1o da mesma Lei e, ainda, caso o objeto da contratação seja relacionado às atividades incluídas em contrato de gestão celebrado com a esfera de governo à qual pertence o órgão ou entidade contratante. (grifo nosso).

Assim, a dispensa de procedimento licitatório abrange apenas os contratos de prestações de serviços realizados entre a organização social e o ente público ao qual se vinculou, não alcançando contratos firmados com outras esferas de governo. 


\section{CAPÍTULO 4 - A PROBLEMÁTICA DA LICITAÇÃO NAS ORGANIZAÇÕES SOCIAIS}

Com a criação das Organizações Sociais surge uma ideia de administração consensual, com o crescimento das atividades de fomento não-exclusivas do Estado. As entidades de colaboração têm maior autonomia para os dirigentes e maior participação popular.

Os requisitos para que uma entidade obtenha a qualificação de OS são: (i) possuir a finalidade não lucrativa; (ii) atuar nas áreas de ensino, pesquisa científica, desenvolvimento tecnológico, defesa do meio ambiente, cultura e saúde; (iii) ter como órgão superior um Conselho Administrativo; (iv) publicar anualmente os relatórios financeiros e de execução do Contrato de Gestão; (v) proibir a distribuição de bens e envio destes para outra OS em caso de extinção; (vi) celebrar contratos de gestão.

Lembre-se, mais uma vez, que estas entidades não pertencem à Administração Pública direita ou indireta, pois são Pessoas Jurídicas de Direito Privado.

A grande questão pertinente a esse estudo é como relacionar as OS com o princípio licitatório. A Lei $\mathrm{n}^{\circ} 8.666 / 93$ disciplina as normas que tratam de licitações e contratos da Administração Pública. O artigo 24 deste diploma enumera as hipóteses de dispensa de licitação, ou seja, a dispensabilidade da licitação, quando autorizada, só libera a Administração Pública do procedimento de escolha da melhor proposta.

O inciso XXIV do art. 24 da Lei ora mencionada- acrescentado por meio da Lei n ${ }^{o}$ 9.648/98-, dispõe sobre a dispensa de licitação no caso de celebração de contratos de prestação de serviços entre o Estado e as organizações sociais, qualificadas no âmbito das respectivas esferas de governo, para prestação de serviços contemplados no contrato de gestão. 
Maria Sylvia Zanella Di Pietro propõe a classificação dos casos de dispensa de licitação em razão do pequeno valor; em razão da pessoa; em razão do objeto; em razão de situações excepcionais. ${ }^{56}$

A dispensa prevista no art. 24, inciso XXIV, da Lei n. 8.666/93 ocorre em razão do sujeito (organização social), que presta atividades por meio de um contrato de gestão, in verbis:

Art. 24 - É dispensável a licitação: XXIV - para a celebração de contratos de prestação de serviços com as organizações sociais, qualificadas no âmbito das respectivas esferas de governo, para atividades contempladas no contrato de gestão.

Da leitura da norma, contudo, observa-se que, além da pessoa, a natureza do objeto, qual seja, a realização da atividade-fim de determinada OS, pode ser considerado um critério adequado para a classificação desta hipótese de dispensa de licitação.

\subsection{A escolha das Organizações Sociais para celebração de contrato de gestão com a Administração Pública}

Percebe-se que a Lei no $9.637 / 98$ não instituiu expressamente sobre a obrigatoriedade de licitação para a escolha da OS que celebrará o contrato com o Estado, o que dá ensejo à discussões doutrinárias acerca da exigência ou não de se realizar procedimento licitatório.

Parte da doutrina interpreta que a escolha de qual OS celebrará contrato de gestão constitui hipótese de dispensa de licitação do Poder Público no momento de escolher com qual organização social celebrará contrato de gestão. Tais autores entendem, que como não há previsão expressa a respeito da obrigatoriedade de licitar, o silêncio do legislador representa uma permissão.

Esta é a opinião de Diogo de Figueiredo Moreira Neto, para quem o

\footnotetext{
${ }^{56}$ DI PIETRO, Maria Sylvia Zanella. Direito Administrativo. 14a ed. São Paulo: Atlas, 2002.
} 
contrato de gestão situa-se fora do campo de incidência da Lei ${ }^{\circ}$ 8.666/93, "pois nem sempre neles estão estabelecidas 'obrigações recíprocas, mas 'obrigações colaborativas',.,57

A doutrina majoritária ${ }^{58}$, entretanto, considera o contrato de gestão como convênio, tendo em vista que na celebração do contrato há interesses convergentes. Por este motivo, a incidência do Estatuto de Licitações não seria obrigatória, nos moldes do art. 116 da Lei $n^{\circ}$ 8.666/93.

Esse posicionamento, por sua vez, é adotado por José dos Santos Carvalho Filho ${ }^{59}$ :

Um deles é o próprio contrato de gestão, que vincula o ente público à organização social; outro é o contrato de prestação de serviço, visando ao cumprimento de atividades ligadas àqueles primeiro ajuste (...). Quanto ao contrato de gestão em si, a dispensa de licitação decorre do próprio sistema implantado na lei reguladora e espelha corolário natural desse tipo de negocio jurídico: a uma, porque se cuida de ajuste de caráter social e, a duas, porque retrata regime de parceria, incompatível com o processo de licitação. Assim, a Administração é livre para escolher a organização social com a qual celebrará o contrato.

Em contrapartida, a segunda corrente doutrinária possui um entendimento intermediário, com base em um procedimento simplificado, com menos exigência formal, de acordo com Claudius Rothenburg ${ }^{60}$.

Nas palavras de Rafael Oliveira é: "necessária a realização de processo objetivo de seleção dos interessados na formalização do contrato de gestão."61 No caso de existir mais de uma entidade interessada, a Administração Pública deve realizar procedimento simplificado para a escolha da OS que celebrará o contrato de gestão.

\footnotetext{
57 MOREIRA NETO, Diogo de Figueiredo. Politicas públicas e parceiras: juridicidade, flexibilidade negocial e tipicidade na Administração Consensual. Revista de Direito do Estado, ano 1, n. 1, p.113, jan./mar. 2006.

58 CARVAlHO FILHO, José dos Santos. Manual de Direito Administrativo. 24a. ed. Rio de Janeiro: Lumen Juris, 2011, p. 236.

${ }^{59}$ Ob. cit., p. 236.

${ }^{60}$ ROTHENBURG, Walter Claudius. Algumas considerações sobre a incidência de direitos fundamentais nas relações do Estado com empresas e organizações sociais. In: OLIVEIRA, Gustavo Justino (Coord.). Terceiro setor, empresas e Estado: novas fronteiras entre o público e o privado. Belo Horizonte: Fórum, 2007. p. 102-103.

${ }^{61}$ OLIVEIRA, Rafael Carvalho Rezende. Administração Pública, Concessões e Terceiro Setor. Rio de Janeiro, Lumen Juris, 2009.
} 
Nesse sentido, leciona Alexandre Santos Aragão:

O contrato de gestão realmente não possui natureza contratual: visa à realização de atividades de interesse comum do Estado e da entidade da sociedade civil, não possuindo, salvo se desvirtuado, caráter comutativo. Esse fato, no entanto, apenas exclui a obrigatoriedade da licitação formal, tal como prevista nas minúcias da Lei n. 8.666/93. Nada leva, contudo, a que o órgão público "contratante" possa deixar de realizar um procedimento objetivo de seleção entre as organizações sociais qualificadas no seu âmbito de atuação para que, de forma impessoal, escolha com qual delas irá realizar a parceria. ${ }^{62}$

Desse modo, constata-se ser mais relevante o cumprimento dos princípios constitucionais que balizam a administração do que as formalidades e exigências presentes na Lei $n^{\circ}$ 8.666/93.

Essa corrente está consubstanciada nos princípios da moralidade, razoabilidade, igualdade, impessoalidade, economicidade e da motivação, previstos no art. 37 da Constituição Federal, no art. $3^{\circ}$ da Lei no 8.666/93 e no art. $7^{\circ}$ Lei n. 9.637/98. Frise-se, oportunamente, que não se pode confundir o fato da dispensa do procedimento licitatório com a escolha desmotivada, livre e sem publicidade prévia, a qual violaria os princípios constitucionais do Estado Democrático de Direito.

A seu turno, o terceiro entendimento doutrinário trata do afastamento da ideia de dispensa de licitação e não admite que a circunstância de excepcionalidade do art. 37, XXI, da Constituição Federal seja aplicada no caso em comento. Para aqueles que se filiam a esta corrente, o legislador não pode agir de forma discricionária ao afastar a exigência de licitação para a seleção dos que poderão celebrar contratos com a Administração, sob pena de desrespeito ao princípio da igualdade.

Isto é, não é admissível que o Poder Público tenha liberdade total para realizar o contrato de gestão, com o intuito de escapar das limitações do direito público. Tal posição se baseia no preceito da igualdade, garantindo a todas as entidades do Terceiro Setor, especialmente neste caso as

\footnotetext{
${ }^{62}$ ARAGÃo, Alexandre Santos de, Direito dos serviços públicos. Rio de Janeiro: Forense, 2008. pp. 748/749;
} 
organizações sociais, o direito a um tratamento isonômico.

Destarte, parece incompatível com o aludido princípio a possibilidade da Administração escolher livremente com qual entidade firmará o contrato de gestão. Portanto, se houver mais de um interessado, realiza-se a licitação, do contrário, contrata-se por inexigibilidade de licitação.

Assim, o Estado é obrigado a submeter seus contratos de gestão ao procedimento de licitação, com fundamento no art. 37, inc. XXI, da CF/88 e em dois princípios fundamentais da licitação, quais sejam: (i) indisponibilidade do interesse público, este deve ser sempre perseguido através da melhor proposta; (ii) isonomia, constituída no tratamento igualitário a todos os concorrentes, afastando qualquer distinção realizada por critérios subjetivos, sendo assim incompatível a escolha de determinada organização social, em detrimentos de outras. ${ }^{63}$

Celso Antônio Bandeira de Mello é manifestamente contrário à dispensa de licitação no caso em comento:

Trata-se, pois, da outorga de uma discricionariedade literalmente inconcebível, até mesmo escandalosa, por sua desmedida amplitude, e que permitirá favorecimentos de toda espécie. Há nisto uma inconstitucionalidade manifesta, pois se trata de postergar o princípio constitucional da licitação (art. 37, XXI) e, pois, o princípio constitucional da isonomia (art. $5^{\circ}$ ), do qual a licitação é simples manifestação pontual, conquanto abrangente também de outro propósito. ${ }^{64}$

Desse modo, o autor critica o contrato de gestão por considerá-lo inconstitucional devido à violação do princípio constitucional da isonomia, o excesso de poder discricionário concedido ao Estado, como também a dispensa de licitação na escolha da Organização Social a ser contratada. Este último motivo fere a Constituição Federal na medida que a Organização Social recebe bens públicos, recursos orçamentários e

\footnotetext{
${ }^{63}$ JUSTEN FILHO, Marçal, Comentários à lei de licitações e contratos administrativos. 12a. ed. São Paulo: Dialética, 2008,, pp. 270/271.

${ }^{64}$ BANDEIRA DE MELLO, Celso Antônio, Curso de Direito Administrativo, 25a . ed., São Paulo: Malheiros Editores, 2008, pp. 238-239.
} 
servidores públicos.

A ausência do procedimento de licitação impede que o Estado dê tratamento igualitário a todas as organizações sociais que queiram celebrar contrato de gestão. Assim se verifica o desrespeito ao princípio da tratamento igualitário a todas as OS que queiram celebrar contratos de gestão, o que consiste em verdadeiro desrespeito ao princípio da obrigatoriedade da licitação, já que a transferência da prestação de serviços públicos para as organizações sociais por simples contrato de gestão seria inconstitucional.

Sendo assim, é forçoso concluir que os princípios constitucionais da isonomia, da impessoalidade e da economicidade não permitem que haja celebração de um contrato de gestão com organização social de forma direta, sem o prévio certame.

Não obstante, Marçal Justen Filho ${ }^{65}$ alega que não resta dúvida quanto a intenção do legislador de usar o contrato de gestão como meio de fuga do regime público. Segundo este autor, a Organização Social presta o serviço público e utiliza-se, para tanto, do patrimônio de servidores e de bens públicos, sendo-lhes aplicável, todavia, o regime de direito privado. Ou seja, as Organizações Sociais não se subordinam às "amarras $d a$ Administração Pública."

Maria Sylvia Zanella Di Pietro ${ }^{66}$ leciona:

Para que a organização social se enquadrasse adequadamente nos princípios constitucionais que regem a gestão de patrimônio publico e existem exatamente para proteger esse patrimônio, seria necessário, no mínimo a exigência de licitação para a escolha da entidade; e submissão aos princípios da licitação.

Importante destacar, ainda, que o alto grau de subjetividade na qualificação das organizações, combinado com as demais previsões da Lei-

\footnotetext{
${ }^{65}$ JUSTEN FILHO, Marçal. Comentários à lei de licitações e contratos administrativos. 12a. ed. São Paulo: Dialética, 2008, p. 267.

${ }^{66}$ DI PIETRO, Maria Sylvia Zanella. Direito Administrativo. 22a. ed, São Paulo: Atlas, 2009, pp. 497-498.
} 
como o de uso de bens públicos, a cessão de servidores públicos e dotações orçamentárias para a prestação de serviços públicos, e a contratação sem licitação- podem dar vazão a desvios e malversações.

Di Pietro entende que, para se tornar constitucional, a lei $\mathrm{n}^{\circ}$ 9.637/98 deveria conter as seguintes exigências: (i) licitação para escolha da entidade; (ii) comprovação de que a entidade já existe, tem sede própria, patrimônio, capital, entre outros requisitos necessários para que uma pessoa jurídica se constitua validamente; (iii) demonstração de qualificação técnica e idoneidade financeira para submissão aos princípios da licitação; (iv) submissão aos princípios da licitação; (v) imposição de limitações salariais quando dependam de recursos orçamentários do Estado para pagar seus empregados; e (vi) prestação de garantia tal como exigida na organização social, pelo fato dela administrar patrimônio público.

José Afonso da Silva sustenta que é necessária a realização da licitação na contratação da OS por se tratar de procedimento administrativo destinado a seleção da proposta mais vantajosa para o Poder Público e por se tratarem de contratos de execução de obras, serviços, compras ou de alienações, nos quais há repasse de recursos públicos. ${ }^{67}$

No presente estudo, compartilha-se da última tese no que tange à obrigatoriedade de licitar para que seja celebrado contrato de gestão entre a entidade e o Poder Público. Em nosso entendimento, a dispensa de licitação ocorrerá apenas em um momento posterior a sua realização, a teor do inciso XXIV do art. 24 da Lei $n{ }^{\circ} 8.666 / 93$.

O Superior Tribunal de Justiça ${ }^{68}$ já firmou entendimento no sentido de que há necessidade de licitar para formalizar o contrato de gestão, já que se tratam de benefícios patrimoniais para a entidade qualificada como OS.

\footnotetext{
${ }^{67}$ SILVA, José Afonso, Curso de Direito Constitucional Positivo, 9a. ed. São Paulo: Malheiros Editores, 1992, p. 573; 276 Art. 40, inc. VI da Lei n. 8.666/93;

${ }^{68}$ BRASIL. Superior Tribunal de Justiça. Recurso Especial $n^{\circ}$ 623.197- RS. Ministro José Delgado. Primeira Turma. Publicação: 8.11.04.
} 
Desse modo, tem-se que a seleção da entidade que realizará contrato de gestão com o Estado, salvo nas hipóteses de dispensa e inexigibilidade, deve ser precedida de licitação.

\subsection{Contratações das OS derivadas do contrato de gestão.}

No que tange à contratação da OS com o fim de desempenhar as atividades estabelecidas no contrato de gestão, o inciso XXIV do art. 24 da Lei $n^{\circ} 8.666 / 93$ autoriza a dispensa de licitação. Assim, a organização social que previamente celebrou contrato de gestão com o Poder Público será diretamente contratada para a prestação de serviços, sem a necessidade de ser precedida de procedimento de licitação.

Marçal Justen Filho interpreta de forma cautelosa a regra do art. 24, XXIV da Lei $n^{\circ}$ 8666/93, para evitar uma exegese que possa ser considerada inconstitucionalidade. Assim, é aplicada na execução das atividades da OS em um momento posterior à celebração do contrato de gestão, considerando, assim, que para a celebração deste é necessário o procedimento licitatório. ${ }^{69}$

Nesse mesmo sentido, José Carvalho dos Santos Filho interpreta o dispositivo em comento:

Um deles é o próprio contrato de gestão, que vincula o ente público à organização social; outro é o contrato de prestação de serviço, visando ao cumprimento de atividades ligadas àqueles primeiro ajuste. A dispensa de licitação teve por foco esta última modalidade de contratos e a hipótese apresenta motivo de fácil compreensão: vinculando-se o Estado à organização social para fins não econômicos por ele alvitrados, não haveria mesmo espaço para que licitasse entre terceiros os serviços decorrentes do contrato, visto que tais serviços são justamente àqueles para os quais a organização social é direcionada. ${ }^{70}$

Dessa forma, uma vez firmado o aludido contrato com o Poder Público, a OS pode ser contratada diretamente para prestação de serviços,

\footnotetext{
${ }^{69}$ JUSTEN FILHO, Marçal. Op. cit.. p. 37.

${ }^{70}$ CARVALHO FILHO, José dos Santos. Op. cit., p. 236.
} 
não tendo que realizar prévio procedimento de licitação. Resta claro a referida situação no artigo em questão, que permite a dispensa de licitação para as futuras contratações de prestação de serviço, já identificadas no contrato de gestão, entre a OS e a Administração.

No momento após a concretização do contrato de gestão, a entidade já estaria com a posse de bens públicos e receberia dotação orçamentária, o que torna incoerente a contratação de outra entidade para desempenhar as atividades que são de sua incumbência.

Cumpre ressaltar que não há violação do princípio da obrigatoriedade de licitação neste caso, visto que o legislador previu expressamente esta hipótese de dispensa de licitação. Ademais, defendemos a constitucionalidade do aludido dispositivo, visto que o art. 37, XXI da CF permite que leis ordinárias criem exceções à regra da licitação, o que ocorre no caso da Lei $n^{\circ} 9.648 / 98$.

Há discussão sobre a obrigatoriedade de licitação, nos termos do artigo 175 da Constituição Federal. Este dispositivo propõe que os serviços públicos que não são prestados diretamente pelo Poder Público devem ser desempenhados por intermédio de concessão ou permissão, tornando obrigatório o procedimento da licitação.

Porém, atente-se para o fato de que as atividades desempenhadas pelas OS não são exclusivas- isto é, não constituem serviços públicos privativos do Estado-, como estabelece o referido artigo. Por essa razão, não há concessão ou permissão nestes casos e tampouco necessidade de tal certame.

Mesmo assim, na doutrina, Celso Antônio Bandeira de Mello entende ser inconstitucional o art. 24, XXIV da Lei $\mathrm{n}^{\circ}$ 8.666/93, tendo em vista o princípio da isonomia, alegando que a não realização da licitação impede a competitividade entre as organizações sociais que atuam na mesma área. 
Além disso, sustenta que, por se tratar repasse de recursos públicos, haveria a necessidade de realizar procedimento licitatório.

Diante do exposto, ousemos, data vênia, refutar o entendimento supracitado, uma vez que a dispensa de licitação é uma exceção à regra constitucional. Com efeito, o mencionado artigo deve ser observado com o máximo de rigor e cautela na sua aplicação, de modo a se evitar a utilização indevida da autorização legal para escapar da realização de licitação.

Destaque-se que há precedente no Egrégio Superior Tribunal de Justiça a amparar tal tese, in verbis:

Administrativo. Contrato de gestão. Licitação. Dispensa. 1. O contrato de gestão administrativo constitui negócio jurídico criado pela Reforma Administrativa Pública de 1990. 2. A Lei n. 8.666, em seu art. 24, inciso XXIV, dispensa licitação para a celebração de contratos de prestação de serviços com as organizações sociais, qualificadas no âmbito das respectivas esferas de governo, para atividades contempladas no contrato de gestão. 3. Instituto Candango de Solidariedade (organização social) versus Distrito Federal. Legalidade de contrato de gestão celebrado entre partes. 4. Ausência de comprovação de prejuízo para a Administração em razão do contrato de gestão firmado. 5. A Ação Popular exige, para sua procedência, o binômio ilicitude e lesividade.6. Recurso especial improvido. ${ }^{71}$

Nesse contexto, o Supremo Tribunal Federal, no julgamento do Recurso Extraordinário n ${ }^{\mathrm{o}} 227.159^{72}$, considerou:

No tocante à inexigibilidade ou dispensa de licitação, totalmente inviáveis as alegações do apelante, pois é claro o preceito do art. 24 , inciso XXIV, da Lei no 8.666/93 ao dispensar a licitação somente para os contratos de prestação de serviços com as organizações sociais para as atividades contempladas no contrato de gestão, que não é o caso dos autos ao tratar da formalização do contrato de gestão, e sim para este é necessário licitação para seleção da organização social, em razão da natureza do contrato de gestão e por envolver destinação de verbas públicas.[...]No mesmo sentido, também descabida a pretensão de inexigibilidade de licitação pela presença de única interessada, sendo que tal situação não está configurada nos autos, porque houve escolha prévia da organização social pelo Município com previsão de destinação orçamentária. Dessa forma, a existência de uma única interessada somente poderá ser, realmente, apurada mediante a realização de procedimento de natureza, eminentemente, seletiva, ao qual tenham acesso todos os possíveis interessados, acrescentando, ainda, a ocorrência de alguma das hipóteses do art. 25 da Lei no 8.666/93.

\footnotetext{
${ }^{71}$ BRASIL. Superior Tribunal de Justiça. Recurso Especial $n^{\circ}$ 952899- DF. Relator: Ministro José Delgado. Órgão Julgador: Primeira Turma. Julgamento: 02.06.2008, Publicação: DJ 23.06.2008, p. 1 .

${ }^{72}$ BRASIL. Supremo Tribunal Federal. Recurso extraordinário $n^{\circ}$ 227.159. Relator: Gilmar Mendes. Julgamento: 04.09.06, Publicação: DJ 20.10.06, p. 103.
} 


\subsection{Obrigatoriedade de regulamento próprio das OS na contratação de empresas prestadoras de serviços, de realização de obras e de fornecimento de bens.}

O art. 17 da Lei $n^{\circ}$ 9.637/98 impõe a necessidade de a OS publicar- no prazo máximo de noventa dias, contado da assinatura do contrato de gestãoum regulamento próprio que fixará os procedimentos adotados para a contratação de obras, bens e serviços.

Por sua vez, o Decreto $n^{0} 5.504$ em 05 de agosto de 2005 exigia que as OS realizassem licitação ao utilizarem os recursos repassados pela Administração Pública, indicando, ainda, que a aquisição de bens e serviços deveria ser feita na modalidade pregão.

Em um momento posterior, o art. 11 do Decreto $n^{\circ}$ 6.170/07 revogou tacitamente à exigência do decreto anterior e determinou que "a aquisição de produtos e a contratação de serviços com recursos da União transferidos a entidades privadas sem fins lucrativos deverão observar os princípios da impessoalidade, moralidade e economicidade, sendo necessária, no mínimo, a realização de cotação prévia de preços no mercado antes da celebração do contrato."

A partir dessa revogação, passou-se a admitir que a entidade privada pode contratar com recursos públicos, livre do procedimento licitatório, mediante simples pesquisa de preços no mercado.

Todavia, entende-se que os dois decretos ferem o art. 17 da Lei $n^{\circ}$ 9.637/98, ensejando violação do princípio da legalidade por parte do Poder Executivo. Vale destacar que o Tribunal de Contas da União ${ }^{73}$ proferiu o entendimento, em hipótese semelhante, que as OS estão obrigadas somente

\footnotetext{
${ }^{73}$ BRASIL. Tribunal de Contas da União. Acórdão $n^{\circ}$ 2.522/2009. $2^{\mathrm{a}}$ Câmara, Ministro-Relator Raimundo Carreiro.
} 
a cumprir com os seus regulamentos próprios, não estando submetidas ao procedimento licitatório formal.

\subsection{Destinação de recursos orçamentários e bens públicos para as Organizações Sociais.}

O artigo 12 da Lei $n^{0}$ 9.637/98 estabelece que o Estado pode destinar às organizações sociais que celebram contratos de gestão recursos orçamentários e bens públicos necessários ao cumprimento desse contrato. $\mathrm{O} \S 3^{\circ}$ deste artigo disciplina que esses bens serão destinados às organizações sociais, mediante permissão de uso.

Todavia, a doutrina questiona tal permissão de uso, uma vez que é discricionária e precária, sem necessidade de autorização legislativa, mas sujeitando-se ao dever de licitar, sempre que houver interessados.

O artigo 13, caput e parágrafo único, da Lei $n^{\circ}$ 9.637/98 estabelecem que os bens móveis públicos permitidos para uso podem ser trocados por outros de igual ou maior valor, desde que (i) os novos bens integrem o patrimônio da União; (ii) haja prévia avaliação do bem; e que haja (iii) expressa autorização do poder público em momento anterior a essa permuta.

A doutrina entende que os artigos supracitados ofendem os princípios constitucionais da isonomia, previsto no artigo $5^{\circ}$, caput e inciso I, da Constituição Federal; da impessoalidade, descrito no artigo 37, caput, da Constituição Federal; da obrigatoriedade de licitação, fixado pelo artigo 37, inciso XXI, da Constituição Federal e; da obrigatoriedade de o poder público prestar serviços públicos, diretamente ou por concessão ou permissão, necessariamente através de licitação, nos moldes do artigo 175 da Constituição Federal.

Conclui-se que a entrega de bens e recursos públicos para uma 
entidade privada sem licitação, enseja tratamento desigual e injustificado entre organizações sociais que se habilitam para contratar com o Poder Público.

De acordo com o entendimento de Maria Sylvia Zanella Di Pietro ${ }^{74}$, a cessão de bens públicos e de recursos orçamentários para as organizações sociais exige ser precedida de procedimento licitatório, com o objetivo de se verificar a idoneidade financeira e a qualificação técnica dessa entidade. Essa habilitação prévia dos licitantes é realizada em todos os contratos administrativos, não havendo justificativa para que não seja exigida nas organizações sociais.

No mesmo sentido, Celso Antônio Bandeira de Mello $^{75}$ também entende ser inconstitucional a cessão de verbas, bens e servidores públicos a uma pessoa jurídica de direito privado qualificada como organização social, sem a devida habilitação técnica ou econômica. Em seus termos, "trata-se, pois, da outorga de uma discricionariedade literalmente inconcebível, até mesmo escandalosa, por sua desmedida amplitude, e que permitirá favorecimentos de toda espécie".

Os referidos autores salientam que tal demonstração é exigida para celebração de qualquer contrato da administração pública com particulares, e nesse caso, há ainda um argumento mais forte, pois há transferência de verbas orçamentárias e bens públicos para pessoas jurídicas de direito privado. A ausência de licitação só é possível nos casos em que haja indiscutíveis razões que justifiquem tal exceção, o que ocorre nesta hipótese, uma vez que tratam-se de recursos públicos.

Diante dessas discussões, tramita no Supremo Tribunal Federal uma

\footnotetext{
${ }^{74}$ DI PIETRO, Maria Sylvia Zanella. Parcerias na Administração Pública: concessão, permissão, franquia, terceirização, parceria público-privada e outras formas. 8a.ed.. São Paulo: Atlas, 2011, p. 270.

75 MELlo, Celso Antônio Bandeira de. Curso de Direito Administrativo. 27a. ed. São Paulo: Malheiros, 2010, p.240.
} 
Ação Direta de Inconstitucionalidade (ADIN n. 1923-DF), sob o argumento de que a Lei n $\mathrm{n}^{\circ}$ 9.638/98 promove a “descaracterização do serviço público, promovendo a pura e simples delegação de atribuições por meio impróprio - firmado com dispensa de licitação (...)” ${ }^{76}$, cujo teor será objeto de estudo do próximo capítulo.

\footnotetext{
${ }^{76}$ BRASIL. Supremo Tribunal Federal. Informativo de Jurisprudência $n^{\circ} 474$.
} 


\section{ORGANIZAÇÕES SOCIAIS NA ADIN N 1.923-DF}

\section{1 - A Ação Direta de Inconstitucionalidade n 1.923-DF}

Em 01.12.1998, o Partido dos Trabalhadores (PT) e o Partido Democrático Trabalhista (PDT) ajuizaram a ação direta de inconstitucionalidade $\mathrm{n}^{\circ}$ 1.923-DF, perante o Supremo Tribunal Federal, na qual foi postulada a declaração de inconstitucionalidade, na íntegra, da Lei $\mathrm{n}^{\circ}$ 9.637/98, que dispõe acerca das organizações sociais, bem como o pedido de inconstitucionalidade do art. 24, XXXIV da Lei no ${ }^{\circ}$ 8.666/93- com redação conferida pela Lei no 9.648/98-, que autoriza a dispensa de licitação para "a celebração de contratos de prestação de serviços com organizações sociais".

Na petição inicial da aludida ADIN, os autores demonstram que a Lei de organizações sociais se insere no âmbito do Programa Nacional de Publicização, que tinha por objetivo justificar a transferência de serviços não exclusivos do Estado para as OS. Tais organizações, por serem entidades de direito privado, gozariam de determinados benefícios.

No entendimento dos autores, a Lei $\mathrm{n}^{\circ}$ 9.637/98 seria uma forma de burlar as obrigações constitucionais atribuídas à Administração Pública, tais como o dever de licitar, o controle do Tribunal de Constas e do Ministério Público e a obrigação de contratação de pessoal por meio de concurso público. Os particulares, que deveriam atuar de forma complementar, passariam a ser os únicos responsáveis pela prestação dos serviços sociais.

Dessa forma, os dois partidos entendem que a lei ora mencionada configuraria tentativa de escapar do regime jurídico de direito público, propiciando que o Estado abandone as funções constitucionais que the foram outorgadas pela Constituição, como, por exemplo, o dever de prestar saúde, educação, serviços nas áreas de proteção ao meio ambiente, ao 
patrimônio histórico e no acesso à ciência (previstos nos arts. 23, 196, 197, 205, 208, 215, 216, $, 1^{\mathrm{o}}, 218$ e 225 da CF), ${ }^{77}$ transferindo a responsabilidade pela atuação nestes setores para as organizações sociais.

\footnotetext{
${ }^{77}$ Constituição Federal, 1988 Art. 23. É competência comum da União, dos Estados, do Distrito Federal e dos Municípios:

I - zelar pela guarda da Constituição, das leis e das instituições democráticas e conservar o patrimônio público;

II - cuidar da saúde e assistência pública, da proteção e garantia das pessoas portadoras de deficiência;

III - proteger os documentos, as obras e outros bens de valor histórico, artístico e cultural, os monumentos, as paisagens naturais notáveis e os sítios arqueológicos;

IV - impedir a evasão, a destruição e a descaracterização de obras de arte e de outros bens de valor histórico, artístico ou cultural;

V - proporcionar os meios de acesso à cultura, à educação e à ciência;

VI - proteger o meio ambiente e combater a poluição em qualquer de suas formas;

VII - preservar as florestas, a fauna e a flora;

VIII - fomentar a produção agropecuária e organizar o abastecimento alimentar;

IX - promover programas de construção de moradias e a melhoria das condições habitacionais e de saneamento básico;

$\mathrm{X}$ - combater as causas da pobreza e os fatores de marginalização, promovendo a integração social dos setores desfavorecidos;

XI - registrar, acompanhar e fiscalizar as concessões de direitos de pesquisa e exploração de recursos hídricos e minerais em seus territórios;

XII - estabelecer e implantar política de educação para a segurança do trânsito.

Parágrafo único. Leis complementares fixarão normas para a cooperação entre a União e os Estados, o Distrito Federal e os Municípios, tendo em vista o equilíbrio do desenvolvimento e do bem-estar em âmbito nacional.
}

Constituição Federal, 1988. Art. 196. A saúde é direito de todos e dever do Estado, garantido mediante políticas sociais e econômicas que visem à redução do risco de doença e de outros agravos e ao acesso universal e igualitário às ações e serviços para sua promoção, proteção e recuperação.

Constituição Federal, 1988 Art. 197. São de relevância pública as ações e serviços de saúde, cabendo ao Poder Público dispor, nos termos da lei, sobre sua regulamentação, fiscalização e controle, devendo sua execução ser feita diretamente ou através de terceiros e, também, por pessoa física ou jurídica de direito privado.

Constituição Federal, 1988 Art. 205. A educação, direito de todos e dever do Estado e da família, será promovida e incentivada com a colaboração da sociedade, visando ao pleno desenvolvimento da pessoa, seu preparo para o exercício da cidadania e sua qualificação para o trabalho.

Constituição Federal, 1988 Art. 208. O dever do Estado com a educação será efetivado mediante a garantia de:

I - educação básica obrigatória e gratuita dos 4 (quatro) aos 17 (dezessete) anos de idade, assegurada inclusive sua oferta gratuita para todos os que a ela não tiveram acesso na idade própria;

II - progressiva universalização do ensino médio gratuito;

III - atendimento educacional especializado aos portadores de deficiência, preferencialmente na rede regular de ensino;

IV - educação infantil, em creche e pré-escola, às crianças até 5 (cinco) anos de idade;

$\mathrm{V}$ - acesso aos níveis mais elevados do ensino, da pesquisa e da criação artística, segundo a capacidade de cada um;

VI - oferta de ensino noturno regular, adequado às condições do educando;

VII - atendimento ao educando, em todas as etapas da educação básica, por meio de programas suplementares de material didático escolar, transporte, alimentação e assistência à saúde. 
$\S 1^{\circ}$ - O acesso ao ensino obrigatório e gratuito é direito público subjetivo.

$\S 2^{\circ}-\mathrm{O}$ não-oferecimento do ensino obrigatório pelo Poder Público, ou sua oferta irregular, importa responsabilidade da autoridade competente.

$\S 3^{\circ}$ - Compete ao Poder Público recensear os educandos no ensino fundamental, fazer-lhes a chamada e zelar, junto aos pais ou responsáveis, pela freqüência à escola.

Constituição Federal, 1988 Art. 215. O Estado garantirá a todos o pleno exercício dos direitos culturais e acesso às fontes da cultura nacional, e apoiará e incentivará a valorização e a difusão das manifestações culturais.

$\S 1^{\circ}$ - O Estado protegerá as manifestações das culturas populares, indígenas e afro-brasileiras, e das de outros grupos participantes do processo civilizatório nacional.

$\S 2^{\circ}$ - A lei disporá sobre a fixação de datas comemorativas de alta significação para os diferentes segmentos étnicos nacionais.

$\S 3^{\circ}$ A lei estabelecerá o Plano Nacional de Cultura, de duração plurianual, visando ao desenvolvimento cultural do País e à integração das ações do poder público que conduzem à:

I defesa e valorização do patrimônio cultural brasileiro;

II produção, promoção e difusão de bens culturais;

III formação de pessoal qualificado para a gestão da cultura em suas múltiplas dimensões;

IV democratização do acesso aos bens de cultura;

V valorização da diversidade étnica e regional.

Constituição Federal, 1988 Art. 216. Constituem patrimônio cultural brasileiro os bens de natureza material e imaterial, tomados individualmente ou em conjunto, portadores de referência à identidade, à ação, à memória dos diferentes grupos formadores da sociedade brasileira, nos quais se incluem: (...)

$\S 1^{\circ}$ - O Poder Público, com a colaboração da comunidade, promoverá e protegerá o patrimônio cultural brasileiro, por meio de inventários, registros, vigilância, tombamento e desapropriação, e de outras formas de acautelamento e preservação

Constituição Federal, 1988. Art. 218. O Estado promoverá e incentivará o desenvolvimento científico, a pesquisa e a capacitação tecnológicas.

$\S 1^{\circ}$ - A pesquisa científica básica receberá tratamento prioritário do Estado, tendo em vista o bem público e o progresso das ciências.

$\S 2^{\circ}$ - A pesquisa tecnológica voltar-se-á preponderantemente para a solução dos problemas brasileiros e para o desenvolvimento do sistema produtivo nacional e regional.

$\S 3^{0}$ - O Estado apoiará a formação de recursos humanos nas áreas de ciência, pesquisa e tecnologia, e concederá aos que delas se ocupem meios e condições especiais de trabalho.

$\S 4^{\circ}$ - A lei apoiará e estimulará as empresas que invistam em pesquisa, criação de tecnologia adequada ao País, formação e aperfeiçoamento de seus recursos humanos e que pratiquem sistemas de remuneração que assegurem ao empregado, desvinculada do salário, participação nos ganhos econômicos resultantes da produtividade de seu trabalho.

$\S 5^{\circ}$ - É facultado aos Estados e ao Distrito Federal vincular parcela de sua receita orçamentária a entidades públicas de fomento ao ensino e à pesquisa científica e tecnológica.

Constituição Federal, 1988 Art. 225. Todos têm direito ao meio ambiente ecologicamente equilibrado, bem de uso comum do povo e essencial à sadia qualidade de vida, impondo-se ao Poder Público e à coletividade o dever de defendê-lo e preservá-lo para as presentes e futuras gerações.

$\S 1^{\circ}$ - Para assegurar a efetividade desse direito, incumbe ao Poder Público:

I - preservar e restaurar os processos ecológicos essenciais e prover o manejo ecológico das espécies e ecossistemas;

II - preservar a diversidade e a integridade do patrimônio genético do País e fiscalizar as entidades dedicadas à pesquisa e manipulação de material genético;

III - definir, em todas as unidades da Federação, espaços territoriais e seus componentes a serem especialmente protegidos, sendo a alteração e a supressão permitidas somente através de lei, vedada qualquer utilização que comprometa a integridade dos atributos que justifiquem sua proteção;

IV - exigir, na forma da lei, para instalação de obra ou atividade potencialmente causadora de significativa degradação do meio ambiente, estudo prévio de impacto ambiental, a que se dará publicidade; 
Outrossim, os autores da ADIN em análise alegam que há violação ao princípio da impessoalidade durante o processo de qualificação das OS, dando brecha à discricionariedade do administrador e afronta ao princípio da legalidade e do concurso público na gestão de pessoal, na medida em que não existe uma lei formal que estabeleça os limites e critérios de remuneração e de despesas com tais funcionários.

Ademais, sustentam a inconstitucionalidade das OS por não se submeterem a controles externos, como, por exemplo, a restrição da atuação do Ministério Público.

Por fim, alegam que a ocorrência de infração à Constituição Federal no que se refere ao dever de licitação, tendo em vista que as OS recebem recursos públicos, ensejaria a observância da Lei Geral de Licitações.

Vale salientar que em 01.08.2007 o pedido de medida cautelar da ADIN n ${ }^{\circ} 1.923$ foi indeferido por maioria no Supremo Tribunal Federal, segundo ementa assim lavrada:

MEDIDA CAUTELAR EM AÇÃO DIRETA DE INCONSTITUCIONALIDADE. LEI N. 9.637, DE 15 DE MAIO DE 1.998. QUALIFICAÇÃO DE ENTIDADES COMO ORGANIZAÇÕES SOCIAIS. INCISO XXIV DO ARTIGO 24 DA LEI N. 8.666, DE 21 DE JUNHO DE 1.993, COM A REDAÇÃO CONFERIDA PELA LEI N. 9.648, DE 27 DE MAIO DE 1.998. DISPENSA DE LICITAÇÃO. ALEGAÇÃO DE AFRONTA AO

V - controlar a produção, a comercialização e o emprego de técnicas, métodos e substâncias que comportem risco para a vida, a qualidade de vida e o meio ambiente;

VI - promover a educação ambiental em todos os níveis de ensino e a conscientização pública para a preservação do meio ambiente;

VII - proteger a fauna e a flora, vedadas, na forma da lei, as práticas que coloquem em risco sua função ecológica, provoquem a extinção de espécies ou submetam os animais a crueldade.

$\S 2^{\circ}$ - Aquele que explorar recursos minerais fica obrigado a recuperar o meio ambiente degradado, de acordo com solução técnica exigida pelo órgão público competente, na forma da lei.

$\S 3^{\circ}$ - As condutas e atividades consideradas lesivas ao meio ambiente sujeitarão os infratores, pessoas físicas ou jurídicas, a sanções penais e administrativas, independentemente da obrigação de reparar os danos causados.

$\S 4^{\circ}$ - A Floresta Amazônica brasileira, a Mata Atlântica, a Serra do Mar, o Pantanal MatoGrossense e a Zona Costeira são patrimônio nacional, e sua utilização far-se-á, na forma da lei, dentro de condições que assegurem a preservação do meio ambiente, inclusive quanto ao uso dos recursos naturais.

$\S 5^{\circ}$ - São indisponíveis as terras devolutas ou arrecadadas pelos Estados, por ações discriminatórias, necessárias à proteção dos ecossistemas naturais.

$\S 6^{\circ}$ - As usinas que operem com reator nuclear deverão ter sua localização definida em lei federal, sem o que não poderão ser instaladas. 
DISPOSTO NOS ARTIGOS 5o; 22; $23 ; 37 ; 40 ; 49 ; 70 ; 71 ; 74$, § 1o E 2o; 129 ; $169, \S 10 ; 175$, CAPUT; 194; 196; 197; 199, § 1o; 205; 206; 208, § 1o E 2o; 211 , 1o; 213; 215, CAPUT; 216; 218, §§ 1o, 2o, 3o E 5o; 225, § 1o, E 209. INDEFERIMENTO DA MEDIDA CAUTELAR EM RAZÃO DE DESCARACTERIZAÇÃO DO PERICULUM IN MORA.

1. Organizações Sociais --- pessoas jurídicas de direito privado, sem fins lucrativos, direcionadas ao exercício de atividades referentes a ensino, pesquisa científica, desenvolvimento tecnológico, proteção e preservação do meio ambiente, cultura e saúde.

2. Afastamento, no caso, em sede de medida cautelar, do exame das razões atinentes ao fumus boni iuris. $O$ periculum in mora não resulta no caso caracterizado, seja mercê do transcurso do tempo --- os atos normativos impugnados foram publicados em 1.998 --- seja porque no exame do mérito poderse-á modular efeitos do que vier a ser decidido, inclusive com a definição de sentença aditiva.

3. Circunstâncias que não justificariam a concessão do pedido liminar. 4. Medida cautelar indeferida. ${ }^{78}$

Ademais, cabe citar a ADIN $\mathrm{n}^{\circ} 1.943-\mathrm{DF}$, proposta pelo Conselho Federal da OAB, que, por tratar da mesma matéria da outra ADIN mencionada, está com seu andamento sobrestado até a decisão desta última.

A partir dessas alegações principais, que fundamentariam a inconstitucionalidade de toda a lei das OS, trataremos dos argumentos defendidos e dos votos já proferidos pelos Ministros do STF no âmbito da ADIN nº 1923.

\section{2 - Síntese dos votos dos Exmos. Ministros Ayres Britto e Luiz Fux}

Até a presente data, em sede da ADIN 1.923-DF, foram proferidos votos dos ministros Carlos Ayres Britto e Luiz Fux. O processo, atualmente, encontra-se no gabinete do ministro Marco Aurélio após pedido de vista.

A síntese do voto proferido pelo Ministro Ayres Britto foi exposta pelo Ministro Luiz Fux em seu voto, senão vejamos:

\footnotetext{
${ }^{78}$ BRASIL. Supremo Tribunal Federal. ADI 1923 MC, Relator: Min. Ilmar Galvão, Tribunal Pleno, Julgamento: 01.08.2007, Publicação: DJ 21.09.07, p. 20.
} 
6. O eminente Min. Relator Ayres Britto, ao trazer o feito a julgamento na sessão plenária de 07 de abril de 2011 , votou pela procedência parcial dos pedidos. Após afirmar que, no campo dos serviços públicos, o Estado é ator por excelência, ressaltou a existência, na Constituição Federal, de serviços públicos não exclusivos, cujo exercício pode se dar também por particulares, de modo que "se prestadas pelo setor público, são atividades públicas de regime jurídico igualmente público", e "se prestadas pela iniciativa privada, óbvio que são atividades privadas, porém sob o timbre da relevância pública", citando como exemplos as disposições constantes dos arts. 194 - seguridade social -, 197, 199, §§1o e 2 o - saúde - , 202, caput e $\S 30$ - previdência privada -, 205, 209, caput, 213, caput e $\S \S 1$ o e 20 educação -, 216, §1o - cultura -, 218, caput e $\S 40$ - desenvolvimento científico, pesquisa e capacitação tecnológicas -, dentre outros.

7. Na sequência, asseverou o Min. Relator que, no campo dos serviços públicos não exclusivos, a atuação da iniciativa privada ocorreria de modo complementar, sem substituir a ação do poder público. Disso decorreria a inconstitucionalidade dos arts. 18 a 22 da Lei no 9.637/98, eis que, ao extinguirem entidades públicas e determinarem a absorção de suas atividades por organizações sociais, configurariam verdadeira substituição do Estado, reservando a este o mero papel de indutor, fiscalizador e regulador, o que seria próprio apenas às atividades econômicas, e não aos serviços públicos. Entendeu o Min. Relator por modular, no ponto, os efeitos da declaração de inconstitucionalidade, preservando os atos praticados até o momento com base no diploma legal.

8. No que pertine, por sua vez, ao modelo geral das Organizações Sociais instituído pela Lei, ressaltou o Min. Relator a circunstância de o contrato de gestão, com a típica natureza de convênio, configurar forma de parceria entre o Estado e os particulares, de modo que, através do repasse de recursos e bens públicos, estaria aquele fomentando a atuação de particulares em áreas dotadas de relevância pública. A natureza de convênio, ainda, afastaria a pecha de inconstitucionalidade com relação às dispensas de licitação previstas no art. 24, XXIV, da Lei no $8.666 / 93$ e no art. 12 , § 3o, da Lei no 9.637/98, desde que observados, invariavelmente, os princípios da impessoalidade, da publicidade e da eficiência, através de um processo público e objetivo para a qualificação das entidades e para as parcerias a serem firmadas, razão pela qual conferiu interpretação conforme aos referidos dispositivos e, ainda, aos arts. 5o, 6o e 7o da Lei, resguardando, em todas as hipóteses, o controle do Ministério Público e do Tribunal de Contas da União à luz da Constituição.

9. Afirmou, nessa mesma linha, a inconstitucionalidade da expressão "quanto à conveniência e oportunidade de sua qualificação como organização social" constante do art. 2o, II, da Lei no 9.637/98, porquanto, ao conferir competência discricionária ao Poder Executivo, mostrar-se-ia incompatível com a objetividade que deve presidir o procedimento de qualificação. Por fim, após considerar que, por não serem funcionários públicos, aos empregados permanentes das Organizações Sociais não seriam aplicáveis os princípios da legalidade na remuneração e do concurso para admissão, reputou inconstitucional a expressão "com recursos provenientes do contrato de gestão, ressalvada a hipótese de adicional relativo ao exercício de função temporária de direção e assessoria", constante do § 20 do art. 14 da Lei no 9.637/98, e, por conseqüência, o $\S 1$ o do mesmo dispositivo, na medida em que, com relação aos servidores públicos cedidos às entidades privadas, 
não seria possível o pagamento de qualquer verba, ainda que privada, sem previsão em lei. ${ }^{79}$

Como se depreende desta leitura, o ministro Carlos Ayres Britto entende que as atividades previstas no art. $1^{\circ}$ da lei das $\operatorname{OS}^{80}$ são de titularidade tanto do Poder Público quanto dos particulares, devendo estes atuarem de forma complementar à ação estatal.

De acordo com a fundamentação deduzida pelo eminente relator, os artigos 18 a 22 da Lei das $\operatorname{OS}^{81}$, que dispõem acerca de transferência de serviços sociais não exclusivos do Estado para organizações sociais, seriam inconstitucionais. $\mathrm{O}$ argumento utilizado em seu voto é que a iniciativa privada estaria substituindo o Poder Público e não o complementando.

No que diz respeito aos contratos de gestão da lei ora mencionada, o ministro não vislumbrou inconstitucionalidade, posto que a Constituição Federal autoriza que tais serviços sejam prestados pelos particulares, juntamente com o fomento do Estado.

O ministro Luiz Fux, por sua vez, divergiu do voto do relator, entendendo pela constitucionalidade de todo o mecanismo de parceria instituído pela Lei das OS. Primeiramente, Fux afasta a incidência do art. 175 da $\mathrm{CF} / 88$, posto que a lei das organizações sociais apenas cria um sistema de fomento; não havendo que se falar, portanto, em delegação da atividade através do contrato de gestão. ${ }^{82}$ Logo, segundo este Ministro, não haveria transferência de atividades do Poder Público para as organizações sociais.

O ministro repele a inconstitucionalidade dos arts. 18 a 22 da Lei em comento, pois, ao contrário do que afirmam os autores na inicial, considera que não há que se falar em delegação do serviço social, porquanto as

\footnotetext{
${ }^{79}$ BRASIL. Supremo Tribunal Federal. ADIN 1923-DF. Relator: Min. ILMAR GALVÃO, Julgamento: 29.06.2007, Publicação: DJ 01.08.2007, p. 15.

${ }^{80}$ Lei Federal 9637, de 15 de maio de 1998.Op. Cit., art. $1^{\circ}$.

${ }^{81}$ Lei Federal 9637, de 15 de maio de 1998. Op. Cit., arts. 18, 19, 20, 21 e 22.

${ }^{82}$ HIGA, Alberto Shiniji. Notas sobre as organizações sociais na ADI n. 1923-DF. Fórum Administrativo-FA, ano 11, n. 127, set. 2011. Belo Horizonte: Fórum, 2011, p.15-28.
} 
entidades privadas prestam serviços sociais por direito próprio. O contrato

de gestão somente possuiria o condão de incentivar que os serviços sejam

desempenhados por particulares, conforme expôs em seu voto:

27. A própria Lei no $9.637 / 98$ menciona expressamente o termo fomento em diversos de sues dispositivos, como se vê de seus arts. 5o, 6o, parágrafo único, e 8o, bem como diretamente da denominação da Seção $V$ - Do fomento às Atividades Sociais da Lei, integrada pelos arts. 11 a 15 . Não há, assim, risco de sucateamento dos setores, que, pela só previsão em lei desse marco regulatório do terceiro setor, não serão colocados à margem do controle do Estado.

28. Portanto, o Poder Público não renunciou aos seus deveres constitucionais de atuação nas áreas de saúde, educação, proteção ao meio ambiente, patrimônio histórico e acesso à ciência, mas apenas colocou em prática uma opção válida por intervir de forma indireta para o cumprimento de tais deveres, através do fomento e da regulação. $\mathrm{Na}$ essência, preside a execução deste programa de ação a lógica de que a atuação privada será mais eficiente do que a pública em determinados domínios, dada a agilidade e a flexibilidade que dominam o regime de direito privado.

29. Ademais, a lei não exige que o Estado saia de cena como um vetor necessário. Decidiu-o, é verdade, com relação a duas concretas entidades públicas mencionadas no art. 21, extinguindo-as e determinando a transferência de recursos, através de contratos de gestão a serem firmados à época, para entidades privadas. Porém, essas decisões específicas tomadas pelo legislador não são, repita-se, uma imposição de um modelo perene de atuação do Poder Público, que pela só edição da Lei no 9.637/98 não se vê obrigado a repeti-lo em hipóteses similares. Ao contrário, a opção pelo atingimento dos resultados através do fomento, e não da intervenção direta, ficará a cargo, em cada setor, dos mandatários eleitos pelo povo, que assim refletirão, como é próprio às democracias constitucionais, a vontade prevalecente em um dado momento histórico da sociedade.

30. Não há sequer como apontar, nessa linha, que aquelas duas decisões políticas específicas tomadas através da edição do art. 21 da Lei, de extinção do Laboratório Nacional de Luz Síncrotron e da Fundação Roquette Pinto, vulnerariam a Constituição. Como se viu mais acima, a moldura constitucional da atuação do Estado nos setores mencionados pela Lei permite a opção tanto pelo prestação direta como pelo fomento, desde que, invariavelmente, a Administração Pública seja controlada do ponto de vista do resultado, sendo por isso válida, em abstrato, a instituição de um marco legal definidor do regime jurídico a ser seguido no modelo de fomento. Ora, se, portanto, seria válida no futuro a escolha pela intervenção através do fomento, não há como enxergar qualquer óbice a que a Lei optasse por fazê-lo pontualmente, desde logo, com relação aos dois setores ocupados pelas referidas entidades.

Quanto à alegação de que a Lei das OS permitiria o Poder Público fugir de funções constitucionais, o eminente ministro esclarece que o art. $1^{\mathrm{o}}$ do citado diploma não constitui abandono dos deveres constitucionais por parte da Administração Pública sob a alegação que a intervenção do Estado 
no domínio econômico e social pode ocorrer de modo direito ou indireto, por meio do fomento público, conforme art. 174, caput da $\mathrm{CF}^{83}$.

Em contrapartida, os votos até então proferidos afastam a obrigatoriedade de licitação para a qualificação de uma entidade privada como organização social. O voto do ministro relator Ayres Britto não menciona tal possibilidade- partindo da premissa que não há licitação-, na medida que se limita a tratar do juízo discricionário na qualificação das OS.

Por sua vez, Luiz Fux afasta o procedimento licitatório para qualificação de entidade como organização social, sustentando que não se trata de hipótese de incidência do art. $37, \mathrm{XXI}$, da CF, ${ }^{84}$ conforme segue: ${ }^{85}$

Pelo regime da lei, os requisitos legais do inc. I do art. $2^{\circ}$ podem ser satisfeitos por todas as associações interessadas - com a ressalva do conteúdo discricionário do inc. II, a seguir analisado. Assim, não há, nesta etapa de qualificação, verdadeira disputa entre os interessados, já que, repita-se, todos que satisfizerem os requisitos poderão alcançar o mesmo título jurídico, de "organização social" a ser concedido pela Administração Pública. A doutrina contemporânea tem feito uso do termo credenciamento para denominar tais casos, em que, repita-se não incide o dever constitucional de licitar pela própria natureza jurídica do ato, que não é contrato, e pela inexistência de qualquer competição, já que todos os interessados podem alcançar o mesmo objetivo, de modo includente e não excludente.

Outra questão abordada na $\mathrm{ADIN} n^{0} 1923$ se refere à possibilidade de concessão do título de organização social ocorrer através de um juízo discricionário. O ministro Ayres Britto votou pela inconstitucionalidade do fraseado "quanto a conveniência e oportunidade de sua qualificação como organização social" constante do art. $2^{\circ}$, II, da lei das $\mathrm{OS}^{86}$. Segundo ele, por se tratar de fase preliminar para formação de parceria com o Estado,

\footnotetext{
${ }^{83}$ BRASIL. Constituição Federal. Art. 174. Como agente normativo e regulador da atividade econômica, o Estado exercerá, na forma da lei, as funções de fiscalização, incentivo e planejamento, sendo este determinante para o setor público e indicativo para o setor privado. ${ }^{84}$ Constituição Federal, 1988. Art. 37. A administração pública direta e indireta de qualquer dos Poderes da União, dos Estados, do Distrito Federal e dos Municípios obedecerá aos princípios de legalidade, impessoalidade, moralidade, publicidade e eficiência e, também, ao seguinte: XXI ressalvados os casos especificados na legislação, as obras, serviços, compras e alienações serão contratados mediante processo de licitação pública que assegure igualdade de condições a todos os concorrentes, com cláusulas que estabeleçam obrigações de pagamento, mantidas as condições efetivas da proposta, nos termos da lei, o qual somente permitirá as exigências de qualificação técnica e econômica indispensáveis à garantia do cumprimento das obrigações.

${ }^{85}$ FUX, Luiz. Op. Cit.

${ }^{86}$ Lei Federal 9637, de 15 de maio de 1998. Op. Cit., art. $2^{\circ}$.
} 
deve ser um ato vinculado para garantir o respeito aos princípios do art. 37 da $\mathrm{CF}^{87}$.

Assim sendo, somente é necessário que a entidade requerente preencha os requisitos dos arts. $2^{\circ}, 3^{\circ}$ e $4^{\circ}$ da Lei das $\operatorname{OS}^{88}$ para que recebam o título, inexistindo discricionariedade. Destaca, ainda, que o ato de qualificação deve ser precedido de um processo objetivo e público, para que seja controlado pelos interessados e pela sociedade.

Por outro lado, o ministro Luiz Fux estabelece ser constitucional, desde que "o procedimento de qualificação seja conduzido de forma pública, objetiva e impessoal, com observância dos principios do caput do art. 37 da CF, e de acordo com parâmetros fixados em abstrato segundo o que prega o art. 20 da lei das OS" $^{89}$

Quanto à celebração do contrato de gestão, os ministros julgam pela ausência de licitação para a celebração de contrato de gestão entre organização social e Poder Público. Segundo eles, não há incidência da norma do art. $37, \mathrm{XXI}$ da $\mathrm{CF}^{90}$ neste caso, visto que o contrato de gestão tem natureza jurídica de convênio, restrita ao âmbito das contratações.

No tocante às exigências para a celebração do contrato de gestão, o ministro Carlos Ayres Britto e Luiz Fux conferiram interpretação segundo a Constituição aos arts. $5^{\circ}$ a $7^{\circ}$ da lei das $\mathrm{OS}^{91}$. Logo, seria necessária a

\footnotetext{
${ }^{87}$ BRASIL. Constituição Federal, 1988. Op. Cit., art. 37.

${ }^{88}$ Lei Federal 9637, de 15 de maio de 1998. Op. Cit., art. $2^{\circ}$.

${ }^{89}$ FUX, Luiz. Op. Cit.

${ }^{90}$ BRASL. Constituição Federal, 1988. Op. Cit., art. 37

${ }^{91}$ Lei Federal 9637, de 15 de maio de 1998. Art. 5ํㅜ Para os efeitos desta Lei, entende-se por contrato de gestão o instrumento firmado entre o Poder Público e a entidade qualificada como organização social, com vistas à formação de parceria entre as partes para fomento e execução de atividades relativas às áreas relacionadas no art. $1^{\circ}$.

Lei Federal 9637, de 15 de maio de 1998. Art. 6º O contrato de gestão, elaborado de comum acordo entre o órgão ou entidade supervisora e a organização social, discriminará as atribuições, responsabilidades e obrigações do Poder Público e da organização social.

Parágrafo único. O contrato de gestão deve ser submetido, após aprovação pelo Conselho de Administração da entidade, ao Ministro de Estado ou autoridade supervisora da área correspondente à atividade fomentada.
} 
realização de um procedimento público e objetivo para a celebração do contrato de gestão, com a devida observância aos princípios constantes no art. 37, da $\mathrm{CF},{ }^{92}$ possibilitando-se, assim, o controle pelos interessados e pela sociedade.

Em suma, os ministros votaram pela desnecessidade do mencionado certame para celebração de contrato de gestão. No entanto, ressaltaram a necessidade do Poder Público de realizar procedimento público e objetivo para a escolha do parceiro.

Outro ponto discutido nos presentes votos diz respeito à contratação da organização social para prestação de atividades previstas no contrato de gestão. O ministro Ayres Britto expôs que ambas as hipóteses de dispensa previstas no art. 12 da Lei $n^{\circ}$ 9637/98 e no art. 24, XXIV da Lei $n^{\circ} 8666 / 03$ não afrontam a Constituição, tendo em vista que os ajustes em questão seriam verdadeiros convênios para os quais não há exigência de licitação.

O ministro Luiz Fux também se manifestou pela constitucionalidade dos dispositivos ora citados, posto que o benefício é concedido com a finalidade de fomentar a entidade na prestação de serviços sociais. Por essa razão, seria legítimo que se dê um tratamento mais vantajoso às OS com o objetivo de se alcançar a eficiência na prestação dos serviços sociais.

\footnotetext{
Lei Federal 9637, de 15 de maio de 1998. Art. $7^{\circ}$ Na elaboração do contrato de gestão, devem ser observados os princípios da legalidade, impessoalidade, moralidade, publicidade, economicidade e, também, os seguintes preceitos:

I - especificação do programa de trabalho proposto pela organização social, a estipulação das metas a serem atingidas e os respectivos prazos de execução, bem como previsão expressa dos critérios objetivos de avaliação de desempenho a serem utilizados, mediante indicadores de qualidade e produtividade;

II - a estipulação dos limites e critérios para despesa com remuneração e vantagens de qualquer natureza a serem percebidas pelos dirigentes e empregados das organizações sociais, no exercício de suas funções.

Parágrafo único. Os Ministros de Estado ou autoridades supervisoras da área de atuação da entidade devem definir as demais cláusulas dos contratos de gestão de que sejam signatários.

${ }^{92}$ Constituição Federal, 1988. Op. Cit., art. 37
} 
Em seu voto, o Ministro salienta que em respeito aos princípios contidos no art. $37, \mathrm{CF}$, a contratação deve ser pública e estar pautada em critérios objetivos e impessoais.

Sob o prisma da contratação de serviços por organizações sociais com uso de verbas públicas, o ministro relator não trata do tema de contratação de terceiros por organizações sociais. Não obstante, o ministro Luiz Fux compreende que a organização social não está obrigada a licitar para contratar com terceiros sob o argumento que de não fazer parte da Administração Pública.

Por receber recursos públicos, as OS deveriam estar sujeitas aos princípios da Administração Pública, de modo que suas contratações devem estar em consonância com o disposto em regulamento próprio, previsto no art. $4^{\circ}$, VIII da lei das $\mathrm{OS}^{93}$, que fixa regras objetivas e impessoais para o uso dos recursos públicos.

Os ministros Ayres Britto e Luiz Fux concordam que a organização social não é um ente da Administração Pública, de modo que as normas previstas no art. 37 , II e $\mathrm{X}$ da $\mathrm{CF}^{94}$ não lhes são aplicáveis. Para eles, os empregados das OS não são considerados servidores públicos, mas sim empregados privados, motivo pelo qual a base de sua remuneração deve ser fixada no contrato de trabalho firmado consensualmente.

Assim, para os aludidos ministros, a seleção de pessoal sem concurso público e a fixação do salário dos empregados/dirigentes de forma consensual não afronta à $\mathrm{CF}$. Entretanto, aqui também devem ser exigidas regras impessoais e objetivas.

No que se refere aos servidores público cedidos, Ayres Britto explica que o art. $14, \S 1^{\circ}$ da Lei das $\mathrm{OS}^{95}$, que autoriza a entidade privada a pagar

\footnotetext{
${ }^{93}$ Lei Federal 9637, de 15 de maio de 1998. Op. Cit., art. $4^{\circ}$.

${ }^{94}$ BRASIL. Constituição Federal, 1988. Op. Cit., art. 37.

${ }^{95}$ Lei Federal 9637, de 15 de maio de 1998. Op. Cit., art.14.
} 
vantagem pecuniária a servidor público, sem previsão legal, viola o art. 37, $\mathrm{X}$ da $\mathrm{CF}$, tendo em vista que ordena que a remuneração dos servidores seja fixada ou alterada mediante lei específica.

De todo modo, o relator também vota pela inconstitucionalidade do art. $14, \S 2^{\circ}$ da Lei das $\mathrm{OS}^{96}$ por afrontar os arts. 37, X e 169, parágrafo primeiro, ambos da $\mathrm{CF}$, uma vez que aquele impõe "adicional relativo ao exercício de função temporária de direção e assessoria".

O ministro Luiz Fux, em contrapartida ao relator, sustenta que o art. 14 , parágrafos $1^{\circ}$ e $2^{\circ}$, não vislumbram qualquer afronta aos arts. $37, \mathrm{X}$ e 169 , parágrafo $1^{\circ} \mathrm{da} \mathrm{CF}$, haja vista que apenas condicionam ao princípio da legalidade os pagamentos aos servidores públicos realizados por entidades da Administração Pública direta e indireta.

Por fim, a Lei das organizações sociais dispõe, no art. $4^{\circ}$, que o conselho de administração será responsável, privativamente, por exercer a fiscalização do cumprimento das diretrizes e metas definidas no contrato de gestão, assim como pela aprovação dos demonstrativos financeiros e contábeis e as contas da entidade.

De acordo com a literalidade da lei, o Tribunal de Contas e o Ministério Público apenas fiscalizariam o cumprimento do contrato de gestão de forma subsidiária caso a entidade ou órgão do Poder Executivo identificasse alguma ilegalidade ou irregularidade na utilização de recursos ou bens públicos.

Todavia, o Exmo. Ministro Luiz Fux proferiu em seu voto interpretação consoante à Constituição Federal, especificamente no que toca aos artigos que dispõem acerca do controle exercido pelo Tribunal de Contas, bem como do Ministério Público, afastando qualquer acepção que limite a atuação desses órgãos.

\footnotetext{
${ }^{96}$ Ibid. Art. 14.
} 
O ministro defende que as organizações sociais, por receberem verbas públicas, estão submetidas ao controle do Tribunal de Contas e do Ministério Público. Entende que o termo "privativo" constante no art. $4^{\circ}$ da lei das OS diz respeito somente à estrutura interna da OS, não possuindo o condão de afastar a competência delimitada constitucionalmente para a atuação do Tribunal de Contas ou do Ministério Público.

Diante do exposto, o relator votou pela procedência parcial da ADIN, declarando inconstitucionais os arts. $2^{\circ}$, II; $14, \S 2^{\circ} ; 18,19,20,21,22$ da Lei 9.637/98. Já o ministro Fux também votou pela procedência parcial, em seus palavras:

66.Ex positis, voto no sentido de julgar parcialmente procedente o pedido, apenas para conferir interpretação conforme à Constituição à Lei no 9.637/98 e ao art. 24, XXIV da Lei no 8666/93, incluído pela Lei no 9.648/98, para que:

(i) o procedimento de qualificação seja conduzido de forma pública, objetiva e impessoal, com observância dos princípios do caput do art. 37 da CF, e de acordo com parâmetros fixados em abstrato segundo o que prega o art. 20 da Lei no 9.637/98;

(ii) a celebração do contrato de gestão seja conduzida de forma pública, objetiva e impessoal, com observância dos princípios do caput do art. 37 da CF; (iii) as hipóteses de dispensa de licitação para contratações (Lei no 8.666/93, art. 24, XXIV) e outorga de permissão de uso de bem público (Lei no 9.637/98, art. 12, §3o) sejam conduzidas de forma pública, objetiva e impessoal, com observância dos princípios do caput do art. 37 da CF;

(iv) os contratos a serem celebrados pela Organização Social com terceiros, com recursos públicos, sejam conduzidos de forma pública, objetiva e impessoal, com observância dos princípios do caput do art. 37 da CF, e nos termos do regulamento próprio a ser editado por cada entidade;

(v) a seleção de pessoal pelas Organizações Sociais seja conduzida de forma pública, objetiva e impessoal, com observância dos princípios do caput do art. 37 da $\mathrm{CF}$, e nos termos do regulamento próprio a ser editado por cada entidade; e

(vi) para afastar qualquer interpretação que restrinja o controle, pelo Ministério Público e pelo TCU, da aplicação de verbas públicas. 


\section{3 - Análise crítica dos votos da ADIN no que concerne à obrigatoriedade da licitação}

No tocante ao controverso tema da subordinação das OS ao princípio da obrigatoriedade do procedimento licitatório, podemos notar dissenso considerável entre os votos dos Ministros e a doutrina brasileira.

O tema pode ser dividido em quatro perspectivas ${ }^{97}$. A primeira referese ao processo de escolha da OS que firmará com o Estado um contrato de gestão. A Lei Federal n $9637 / 98$ não submeteu esta escolha a um processo de licitação, embora os Ministros indiquem que há exigência de um processo de seleção pública e com a observância dos princípios constitucionais.

Frise-se que este posicionamento é filiado a uma corrente intermediária, abalizada por Diogo de Figueiredo Moreira Neto, ora mencionado no capítulo 2 do presente estudo. Com data vênia ao entendimento dos Ministros, há como vislumbrar violação do princípio da isonomia, posto que a escolha não se sujeita ao procedimento licitatório.

A segunda perspectiva diz respeito à contratação da organização social para prestação de atividades previstas no contrato de gestão, na qual poderia ser diretamente contratada por entidades da mesma esfera federativa com a qual contratou, conforme o art. 24, XXIV da Lei 8.666/93.

Comungamos do mesmo posicionamento manifestado até o momento na ADIN sob estudo, qual seja, de que não haveria desrespeito ao art. 37, $\mathrm{XXI}$ da $\mathrm{CF}$, na medida em que o legislador previu esta hipótese de dispensa de licitação por se tratar de atividade de fomento, o que confere a este vínculo colaborativo um regime especial.

\footnotetext{
${ }^{97}$ OLIVEIRA, Gustavo Henrique Justino de. As organizações sociais e o Supremo Tribunal Federal. Fórum Administrativo-FA, ano 8, n. 86, abr. 2008. Belo Horizonte: Fórum, 2008, p.7-16.
} 
O terceiro aspecto relaciona-se com as contratações de serviços, bens e obras por parte das OS. Essa tese está veiculada pelo art. 17 da Lei 9.637/98, ou seja, a entidade é submetida a um regulamento próprio, contendo procedimentos e normas acerca dessas contratações.

Por fim, a quarta perspectiva é atinente a remessa de bens públicos às OS. Embora essa questão não tenha sido explicitamente elencada na ADIN 1923-DF, os Ministros defendem a constitucionalidade do art. 12 da Lei das OS que trata dessa questão, por ser atividade de fomento estatal a entidades privadas que se submetem a um regime especial. Todavia, não compartilhamos desse entendimento. Ressalte-se, mais uma vez, que, neste caso, há o dever de licitar, justificado por haver de remessa de recursos públicos.

Em suma, o contrato de gestão firmado entre as organizações sociais e as entidades do Poder Público, foi instituído com o objetivo de garantir a adequada prestação dos serviços públicos de ordem social.

As OS são incumbidas de desempenhar os serviços sociais de modo que a população tenha maior eficiência e qualidade nos serviços prestados. No entanto, conforme analisado neste capítulo, a Lei ${ }^{\circ} 9.637 / 98$ possui várias falhas, ao estabelecer condições demasiadamente benéficas às organizações sociais.

Por essa razão, nos dias atuais, essa temática ganhou extrema importância, visto que as organizações sociais não podem substituir por completo o Estado nos serviços desempenhados por ele, devendo, sim, haver um complemento, visando a prestação de serviços de qualidade e efetividade à população.

Dessa forma, reputa-se necessário que a lei das OS seja observada em consonância com os limites estabelecidos pela Constituição Federal, sendo imprescindível e de máxima urgência o julgamento da ADIN nº 1923-DF.. 
Entendemos que ainda que sejam necessários os demais votos na ADIN 1923-DF, a legislação de regência das organizações sociais está parcialmente eivada de vícios de inconstitucionalidade, o que também deve ser definido a partir da decisão definitiva do Supremo Tribunal Federal. 


\section{CONCLUSÃO}

Ao longo do presente trabalho, procurou-se analisar as razões que redefiniram o papel da Administração Pública nos dias atuais. Assim, em um primeiro momento, a partir do contexto ora assinalado, de transformação do direito administrativo brasileiro, foi destacada a intensificação das relações entre a sociedade civil e o Estado.

Observou-se brevemente na evolução histórica a importância da soberania popular que deu ensejo ao chamado Terceiro Setor. No Brasil, tal setor se caracteriza como "o conjunto de atividades voluntarias, desenvolvidas por organizações privadas não- governamentais e sem animo de lucro, realizadas em prol da sociedade, independentemente dos demais setores, embora com eles posso firmar parcerias e deles possa receber investimentos. ${ }^{" 98}$

O princípio da subsidiariedade e o fomento justificam a atuação dessas entidades como parceiras do Estado, pois, em sua essência, visam à prestação dos serviços públicos de maneira mais adequada e satisfatória, ampliando sua eficácia.

Apenas à titulo de esclarecimento, o Terceiro Setor é composto pelos serviços sociais autônomos, pelas OS, pelas OSCIPs e pelas entidades de apoio.

Nesse contexto, a criação da lei das organizações sociais é considerada como uma forma de parceria entre entidades de direito privado sem fins lucrativos e o Poder Público, constituindo verdadeiro marco legal.

\footnotetext{
${ }^{98}$ Oliveira, Gustavo Henrique Justino de. As organizações sociais e o Supremo Tribunal Federal. Fórum Administrativo-FA, ano 8, n. 86, abr. 2008. Belo Horizonte: Fórum, 2008, p.16.
} 
Salienta-se que essas entidades devem ser dotadas de expertise, para que possam prestar com eficiência e qualidade os serviços sociais previstos no art. $1^{\mathrm{o}}$ da Lei supracitada.

As entidades que tiverem por objeto a prestação de serviços relacionados à educação, à pesquisa científica, ao desenvolvimento tecnológico, proteção e preservação do meio ambiente, cultura e saúde, bem como preencherem determinados requisitos constantes da Lei, poderão ser qualificadas como organizações sociais para posteriormente celebrar contrato de gestão com o Poder Público. A partir desse instrumento que formaliza a parceria, tais entidades começam a receberão benefícios do parceiro público, tais como o repasse de verbas públicas, servidores e bens.

Partindo-se de tais premissas, a presente monografia dissertou acerca do contexto do surgimento da lei das organizações sociais, com especial destaque aos fundamentos que embasaram tal promulgação. Também abordou de modo mais detalhado as principais características da parceria, instituída pela referida lei.

No entanto, conforme se demonstrou no presente estudo, a Lei $\mathrm{n}^{\circ} 9.637 / 98$ possui diversas distorções, ao estabelecer condições demasiadamente benéficas às organizações sociais, condições essas que muitas vezes contrariam o regime jurídico administrativo imperante na prestação de serviços públicos, em especial no que concerne à questão do procedimento licitatório das OS.

Com efeito, a licitação é o ponto nodal no estudo das organizações sociais, motivo pelo qual destacou-se a importância do procedimento de licitação para a Administração Pública.

Como visto, define-se licitação como o procedimento administrativo pelo qual a Administração Pública abre a todos os interessados, observada a igualdade entre eles e respeitadas as condições impostas no instrumento 
convocatório, a possibilidade de apresentarem suas propostas dentre as quais será selecionada a mais vantajosa aos seus interesses..

Para tanto, foi necessária uma prévia conceituação de alguns pontos intrínsecos ao assunto estudado, sobretudo acerca dos princípios que regem tal matéria. Tratou-se, portanto, dos princípios da legalidade, impessoalidade, impessoalidade, publicidade, probidade administrativa, vinculação ao instrumento convocatório e julgamento objetivo.

Conforme referido, a própria Lei $\mathrm{n}^{\mathrm{o}} 8.666 / 93$ permite a dispensa de licitação, pautada na discricionariedade do administrador, observado o princípio da razoabilidade, para atender ao interesse público. Tais hipóteses estão arroladas em uma lista exaustiva, ${ }^{99}$ dentre as quais encontra-se a mais relevante para a presente monografia- prevista no inciso XXIV do art. 24 da Lei 8.666/93-, por se tratar de hipótese de dispensa de licitação que permite a contratação direta de organizações sociais pela Administração Pública. Como amplamente exposto, esse dispositivo gerou uma grande discussão na doutrina.

Adentrando com mais profundidade no problema proposto, o trabalho abordou as teses dos principais juristas a respeito da exigibilidade de prévio processo licitatório para a qualificação de entidades como organizações sociais, para a celebração de contratos de gestão e para a contratação com particulares, na execução do contrato de gestão pelas organizações sociais, bem como o repasse de recursos e bens públicos a essas entidades.

Em seguida, diante dessa controvérsia, o estudo das OS foi dividido em quatro aspectos em relação à necessidade ou não de se observar a Lei Geral de Licitações. Dentre todas as classificações apresentadas, a que guardou maior destaque refere-se ao processo de escolha da OS que firmará

\footnotetext{
${ }^{99}$ JUSTEN FILHO, Marçal, Comentários à lei de licitações e contratos administrativos. 12. ed. São Paulo: Dialética, 2008, p. 233.
} 
contrato de gestão com o Estado, tendo em vista a ausência de disciplina legal acerca do assunto.

Por fim, o trabalho apresenta um breve resumo das ponderações aduzidas na Ação Direta de Inconstitucionalidade n 1.923 , na qual se busca o reconhecimento da inconstitucionalidade de diversos dispositivos da Lei $\mathrm{n}^{\circ} 9.637 / 98$. A constitucionalidade da lei acerca das OS foi questionada pelos partidos PT e PDT, por entenderem que, nos moldes em que foi estabelecida a lei das organizações sociais, o Estado estaria buscando mais do que instituir um modelo de parceria com entidades privadas, estaria deixando de lado suas atribuições como prestador dos serviços sociais, delegando-as para as organizações sociais.

A lei também seria inconstitucional na medida em que tenta reflexibilizar exigências do regime de direito público previstas para a administração, especialmente no que tange à problemática da licitação nas OS.

A ADIN ainda não foi julgada pelo Supremo Tribunal Federal, tendo sido proferidos apenas os votos do Ministro relator, Carlos Ayres Britto e do Ministro Luiz Fux. Entretanto, o indeferimento da cautelar e o conteúdo dos votos ora prolatados apontam para a parcial constitucionalidade de grande parte da lei de organizações sociais.

Em suma, a presente pesquisa objetivou a confrontação de alegações da doutrina administrativa, a fim de traçar o entendimento que possa ser considerado mais razoável sobre a matéria em cotejo.

Como amplamente abordado, a OS tem como finalidade a desburocratização e aprimoramento da prestação de serviços públicos, razão pela qual não deveria se submeter ao procedimento formal licitatório. No entanto, ao receberem recursos públicos do parceiro estatal para 
atendimento das metas pré-estabelecidas no contrato de gestão, não podem ignorar por completo os ditames de direito público, conforme exposto.

Assim, entendemos que a validação em parte da referida lei representa um passo relevante para o fortalecimento de novas formas colaborativas entre o setor público e o privado. 


\section{REFERÊNCIAS BIBLIOGRÁFICAS}

ALEXANDRINO, Marcelo. Direito Administrativo Descomplicado. 20a. ed. São Paulo: Método, 2012.

ARAGÃO, Alexandre Santos de. Curso de direito administrativo. 1a. ed. Rio de Janeiro: Forense, 2012.

ARAGÃO, Alexandre Santos de. Direito dos serviços públicos, Rio de Janeiro: Forense, 2008.

BACELLAR FILHO, Romeu Felipe. O regime jurídico das organizações sociais e sua contratação pelo Poder Público mediante dispensa de licitação. Interesse Público, ano 11, n. 58. Belo Horizonte: Fórum, 2009. pp. 11-30.

BANDEIRA DE MELlO, Celso Antônio, Curso de Direito Administrativo, 25a. ed. São Paulo: Malheiros Editores, 2008.

BINENBOJM, Gustavo. Temas de Direito Administrativo e Constitucional. Rio de Janeiro: Renovar, 2008.

BRASIL. Superior Tribunal de Justiça. Recurso Especial $n^{o} 623.197$ - RS. Ministro José Delgado. Primeira Turma. Publicação: 8.11.04.

BRASIL. Superior Tribunal de Justiça. Recurso Especial $n^{o} 952.899$ - DF. Relator: Ministro José Delgado. Órgão Julgador: Primeira Turma. Julgamento: 02.06.2008, Publicação: DJ 23.06.2008.

BRASIL. Supremo Tribunal Federal. ADI 1923 DF, Relator: Min. Ilmar Galvão, Tribunal Pleno, Julgamento: 29.06.2007, Publicação: DJ 01.08.2007, p. 15.

BRASIL. Supremo Tribunal Federal. Informativo de Jurisprudência $n^{\circ} 474$.

BRASIL. Supremo Tribunal Federal. Recurso extraordinário $n^{\circ}$ 227.159. Relator: Gilmar Mendes. Julgamento: 04.09.06, Publicação: DJ 20.10.06. 
BRASIL. Tribunal de Justiça do Distrito Federal-DF. Embargos infringentes em apelação $n^{o}$ 0091469-95.1999.807.0001. Relator: Otávio Augusto. Órgão Julgador: $1^{\text {a }}$ Câmara Cível. Julgamento: 20.11.06, Publicação: 30.11.06.

BRASIL, Presidente. PLANO DIRETOR DA REFORMA DO APARELHO DO ESTADO: Presidência da República, Câmara da Reforma do Estado, Ministério da Administração Federal e Reforma do Estado, 1995.

BRASIL. Tribunal de Contas da União. Acórdão $n^{o}$ 2.522/2009, 2a. Câmara, Ministro-Relator Raimundo Carreiro.

BRASIL. Tribunal de Contas da União. Decisão $n^{o}$ 907/07. Plenário. Ata $\mathrm{n}^{\mathrm{o}}$ $53 / 97$.

CARDOSO, Ruth. Fortalecimento da sociedade civil. In: IOSCHPE, E. B. (org.). Terceiro Setor: Desenvolvimento Social Sustentado. 2a. ed. São Paulo: GIFE, 2000 .

CARVAlHO FILHO, José dos Santos. Manual de Direito Administrativo. 24a. ed. Rio de Janeiro: Lumen Juris, 2011.

DALLARI, Adilson Abreu. Aspectos jurídicos da licitação. 4a. ed. São Paulo: Saraiva, 1997.

DI PIETRO, Maria Sylvia Zanella. A defesa do cidadão e da republica. Revista do Serviço Público. Brasília: ENAP, Ano 49, número 2, 1998, p. 128.

DI PIETRO, Maria Sylvia Zanella. Direito Administrativo. 25a. ed. São Paulo: Atlas, 2012.

DI PIETRO, Maria Sylvia Zanella. Parcerias na Administração Pública: concessão, permissão, franquia, terceirização, parceria público-privada e outras formas. 8a.ed.. São Paulo: Atlas, 2011.

ESPIRITO SANTO, Ataliba Pinheiro. As organizações sociais e a Reforma Administrativa. Revista de Direito Administrativo. n. 230, out/dez 2002. Rio de Janeiro: Renovar, 2002. 
FERRAZ, Luciano de Araújo. Poder Público e Terceiro Setor: considerações acerca do dever de licitar e anteprojeto da lei da nova organização administrativa brasileira. Interesse Público. Ano 12, n. 64. Belo Horizonte: Fórum, 2010, p.75-83.

GARCIA, Flávio Amaral. Licitações e contratos administrativos: casos e polêmicas. 2a. ed. Rio de Janeiro: Lumen Juris, 2009.

GASPARINI, Diógenes. Direito Administrativo. 15a. ed. São Paulo: Saraiva, 2010.

HIGA, Alberto Shiniji. Notas sobre as organizações sociais na ADI n. 1923-DF. Fórum Administrativo-FA, ano 11, n. 127, set. 2011. Belo Horizonte: Fórum, 2011, p.15-28.

JUSTEN FILHO, Marçal. Comentários à Lei de Licitações e Contratos Administrativos. 12a. ed. São Paulo: Dialética, 2008.

JUSTEN FILHO, Marçal. Curso de direito administrativo. São Paulo: Saraiva, 2005.

MADAUAR, Odete. Direito Administrativo Moderno. 13a. ed. São Paulo: Revista dos Tribunais, 2009.

MÂNICA, Fernando Borges. Panorama Histórico- legislativo do terceiro Setor no Brasil: Do conceito de Terceiro Setor à Lei das OSCIP. In: OLIVEIRA, Gustavo Henrique Justino de. Direito do Terceiro Setor: Atualidades e Perspectivas. Curitiba: Ordem dos advogados do Brasil. Seção do Paraná, 2006.

MEIRELLES, Hely Lopes. Direito Administrativo Brasileiro. São Paulo: Malheiros Editores, 2001.

MELlO, Celso Antônio Bandeira de. Curso de Direito Administrativo. 27a. ed. São Paulo: Malheiros, 2010.

MODESTO, Paulo. O direito administrativo do terceiro Setor: a aplicação do direito público às entidades privadas sem fins lucrativos. Revista Brasileira de Direito Público, ano 9, n. 33, abr. 2011. Belo Horizonte: Fórum, 2011, pp.1-8. 
MORALES, Carlos Antônio. Provisão de serviços sociais através de organizações públicas não-estatais. In: PEREIRA, Luiz Carlos Bresser. O público não-estatal na reforma do Estado. Rio de Janeiro: Fundação Getúlio Vargas, 1999.

MOREIRA NETO, Diogo de Figueiredo. Quatro Paradigmas do Direito Administrativo Pós-Moderno: legitimidade, finalidade, eficiência, resultados. Belo Horizonte: Fórum, 2008.

MOREIRA NETO, Diogo de Figueiredo. Mutações do Direito Administrativo. Rio de Janeiro: Renovar, 2000.

MOREIRA NETO, Diogo de Figueiredo. Políticas públicas e parceiras: juridicidade, flexibilidade negocial e tipicidade na Administração Consensual. Revista de Direito do Estado, ano 1, n. 1, p.113, jan./mar. 2006.

OLIVEIRA, Gustavo Henrique Justino de. As organizações sociais e o Supremo Tribunal Federal. Fórum Administrativo-FA, ano 8, n. 86, abr. 2008. Belo Horizonte: Fórum, 2008, p.7-16.

OLIVEIRA, Gustavo Henrique Justino de. Constitucionalidade da Lei Federal $n$. 9.637/98, das organizações sociais: comentários a medida cautelar da ADIN n. 1923-DF, do Supremo Tribunal Federal. Revista de Direito do Estado, ano 2, n. 8, out/dez. Rio de Janeiro: Renovar, 2006, pp 345-382.

OLIVEIRA, Gustavo Henrique Justino de. Estado contratual, direito ao desenvolvimento e parceria público- privada. In: TALAMINI, Eduardo et al. ( Coord.). Parceria público-privada: uma abordagem multidisciplinar. São Paulo: Revista dos Tribunais, 2005. p. 86.

OLIVEIRA, Rafael Carvalho Rezende. Administração Pública, Concessões e Terceiro Setor. Rio de Janeiro: Lumen Juris, 2009.

OLIVEIRA, Rafael Carvalho Rezende. Direito Administrativo. 22a. ed. São Paulo: Atlas, 2009.

ROTHENBURG, Walter Claudius. Algumas considerações sobre a incidência de 
direitos fundamentais nas relações do Estado com empresas e organizações sociais. In: OLIVEIRA, Gustavo Justino (Coord.). Terceiro setor, empresas e Estado: novas fronteiras entre o público e o privado. Belo Horizonte: Fórum, 2007. p. 102-103.

SILVA, Carlos Medeiros. Revista de Direito Administrativo. 230a. ed. Rio de Janeiro: Renovar Ltda., 2002.

SILVA, José Afonso, Curso de Direito Constitucional Positivo, 9a. ed. São Paulo: Malheiros Editores, 1992.

SOUTO, Marcos Juruena Villela. Tópicos de licitações. Rio de Janeiro: Lumen Juris, 1999.

SPARAPANI, Priscilia; ADRI, Renata Porto (Coord.). Intervenção do Estado no domínio econômico e no domínio social: homenagem ao Professor Celso Antônio Bandeira de Mello. Belo Horizonte: Fórum, 2010.

VASCONCELOS, Edson Aguiar de, Direito Constitucional Administrativo. 1a. ed. Rio de Janeiro: GZ Ed., 2010. 